\title{
Weldability Investigation and Optimization of Process Variables for TIG-Welded Aluminium Alloy (AA 8006)
}

\author{
T. Sathish $\mathbb{D}^{1},{ }^{1}$ S. Tharmalingam, ${ }^{2}$ V. Mohanavel $\left(\mathbb{D},{ }^{3}\right.$ K. S. Ashraff Ali, ${ }^{4}$ Alagar Karthick $\left(\mathbb{D},{ }^{5}\right.$ \\ M. Ravichandran $\left(\mathbb{D},{ }^{6}\right.$ and Sivanraju Rajkumar $\mathbb{D}^{7}$
}

${ }^{1}$ Department of Mechanical Engineering, Saveetha School of Engineering, SIMATS, Chennai 602105, Tamil Nadu, India

${ }^{2}$ Department of Mechanical Engineering, Chendhuran Polytechnic College, Pudukkottai 622507, Tamil Nadu, India

${ }^{3}$ Centre for Materials Engineering and Regenerative Medicine, Bharath Institute of Higher Education and Research, Chennai 600073, Tamil Nadu, India

${ }^{4}$ Department of Mechanical Engineering, C. Abdul Hakeem College of Engineering \& Technology, Vellore 632509, Tamil Nadu, India

${ }^{5}$ Department of Electrical and Electronics Engineering, KPR Institute of Engineering and Technology, Coimbatore 641407, Tamil Nadu, India

${ }^{6}$ Department of Mechanical Engineering, K. Ramakrishnan College of Engineering, Trichy 621112, Tamil Nadu, India

${ }^{7}$ Department of Mechanical Engineering, Faculty of Manufacturing, Institute of Technology, Hawassa University, Hawassa, Ethiopia

Correspondence should be addressed to Sivanraju Rajkumar; rajkumar@hu.edu.et

Received 9 April 2021; Revised 25 June 2021; Accepted 12 July 2021; Published 23 July 2021

Academic Editor: Ştefan Ţălu

Copyright (c) 2021 T. Sathish et al. This is an open access article distributed under the Creative Commons Attribution License, which permits unrestricted use, distribution, and reproduction in any medium, provided the original work is properly cited.

\begin{abstract}
Aluminium and its alloys play a significant role in engineering material applications due to its low weight ratio and superior corrosion resistance. The welding of aluminium alloy is challenging for the normal conventional arc welding processes. This research tries to resolve those issues by the Tungsten Inert Gas welding process. The TIG welding method is an easy, friendly process to perform welding. The widely applicable wrought aluminium AA8006 alloy, which was not considered for TIG welding in earlier studies, is considered in this investigation. For optimizing the number of experiments, the Taguchi experimental design of $L_{9}$ orthogonal array type experimental design/plan was employed by considering major influencing process parameters like welding speed, base current, and peak current at three levels. The welded samples are included to investigate mechanical characterizations like surface hardness and strengths for standing tensile and impact loading. The results of the investigation on mechanical characterization of permanent joint of aluminium AA8006 alloy TIG welding were statistically analyzed and discussed. The 3D profilometric images of tensile-tested specimens were investigated, and they suggested optimized process parameters based on the result investigations.
\end{abstract}

\section{Introduction}

In recent trends, aluminium alloys have been broadly applied in various work fields, being simple in construction, carriage, and marine and advanced aerospace application like wing sections, etc. Its magnificent performance will be used to fabricate lightweight containers in sheet metal work. Typically aluminum alloys are in the same light time; they will be of high strength and flexible nature. The combination of good corrosion resistance and excellent wear resistance is possessed in aluminium alloys. The permanent and rigid joining of aluminum alloy was carried out through the welding process; in the normal welding process, aluminum alloy's consolidation is challenging. Nowadays, aluminium alloys are welded simply using TIG welding for various thicknesses of the specimen. Comparatively the TIG welding process yields high quality welding joints (lesser defects), easy and faster than arc welding. Microstructural grains 
strength is improved in the TIG welding process, and it is noted in the mechanical strength analysis. High-quality welding was obtained compared to another welding process. It is an added advantage in the TIG welding process.

Aluminum has a mixture of properties quite difficult to find in our world: lightweight, very strong, very malleable, and nonreactive. It is the lightest metal on Earth, exceptionally bendable and rustproof due to a thin layer of chromium on its surface and is equally powerful. It does not magnetize all types of metal (except for some less-ferromagnetic metals), rendering it ineffective as a fantastic conductor of electricity [1]. Friction welding, also because the weldment generates low heat, means that residual stresses are kept low. A transverse force in wench (also known as transverse or transverse frictional force) is employed in stress measurement [2] Dengkui et al. [3] revealed that the material's mechanical properties are changed by applications of different geometric shapes. The authors studied and reported that weld joints characterization such as weld width, penetration depth, and the reinforcement process profiles could achieve it. The mechanical properties were altered, and enhanced strength was also obtained. From this study, the WZ and PMZ hardness values were decreased and weaken the joints and mechanical properties. Aravind and Daniel Das [4] suggested that the maximum welding strength attained using the process parameters (current, welding speed, and welding time) achieving the optimum tensile strength is $130.27 \mathrm{MPa}$. The $\mathrm{S} / \mathrm{N}$ ratio also states that to ensure the maximum weld strength. Ramandeep et al. [5] revealed the welding current raised the hardness of the weld joint. For their study, the welded specimens' properties are affected by the welding defects like porosity, which reduces its tensile strength. Gurmeet et al. [6] analyzed experimental comparison of TIG welding and FSW process to understand the metallurgical properties of the base material and welded area. Further their study found the hardness of the TIG welding joint and compared it to other welding joints. Lakshman et al. [7] suggested that the TIG-welded aluminium alloy offered maximum tensile strength by influencing optimum process parameters such as welding speed, gas flow rate, and welding current. In this study, they recommended better results in the post-heat-treatment process, even using different materials. Ji-Kun et al. [8] performed the TIG welding of aluminium alloy 2219. It proved the enhanced properties of hardness and tensile occurring in the postweld heat-treatment process. They also concluded that the higher elongation and impact toughness could be obtained by implementing postweld heat treatment. Temmar et al. [9] stated the AA7075 welded joints' tensile strength was increased by applying postweld aging behavior. In the AA7075-welded joints, the significant effect decreases the impact energy.

Adalarasan et al. [10] reported that the aluminium alloy 6061 has to be welded by the TIG welding process, the optimal process parameters as $24 \mathrm{~V}, 180 \mathrm{Amps}, 110 \mathrm{~mm} / \mathrm{min}$ welding speed, and gas flow at the rate of $12 \mathrm{l} / \mathrm{min}$. They also evaluated the significant contribution of welding current through ANOVA and considered the primary controllable parameter. Sethuraman et al. [11] studied the optimization parameters of peak current $(130,150$, and 170 Amps), base voltage $(20,25,30 \mathrm{Amps})$, and gas pressure $\left(4,5,6 \mathrm{~kg} / \mathrm{cm}^{2}\right)$ of TIG welding on AA6063. The effect of each individual parameter was found, which is the most appropriate one with the help of ANOVA and regression analysis. Shanavas et al. [12] made analysis to obtain the most suitable parameters such as $180 \mathrm{Amps}, 100 \mathrm{~mm} / \mathrm{min}$ welding speed, and inert gas float $11 \mathrm{l} / \mathrm{m}$. They also concluded the superior tensile strength was obtained more than other joints. With the best of the search, the weldability studies in the TIG method for Aluminum AA8006 alloy were not reported in the literature. Joints have become much more prone to fatigue, making the aluminum 2219 more difficult to weld than originally thought. Researchers have developed a number of mechanisms to try to handle these constraints that incorporate AC TIG (addressing everything soldering), VPT (validating every parameter), and plasma solutions to develop VPT (resolving all the problems of curability). Nonetheless, there has been no solution to the instability/ inconsistency and the cycle of the welding procedure for the $\mathrm{AC}$ technique, to the point where it is no longer an issue. In order to use the variable polarity plasma soldering device, a solder joint must be created that is successful. High-perforge layers must be used for the job of soldering large sheets of aluminum, and a large amount of heat is required. Despite being smaller than usual for an AC TIG process, the current used is still high [13-16]. For AA6061 and AA7075, a comparison of TIG and FSW residual stresses revealed that the longitudinal residual stress is greater than the traverse residual stress in the welded joint [17]. The comparative investigations in terms of heat transfer and residual stress were not properly analyzed in the literature. The residual stresses and heat transfer affect the welding quality at the beginning and end of the joints. In thin plate welding, in analyzed cases it was found that the increase of spindle rotation in friction stir welding increases the tensile strength on joints initially and it declines after certain extent. The microhardness of the welded joint was measured by three layers (i.e., the top, middle, and bottom). The upper layer of bonding has a higher degree of recrystallization and dynamic recovery. The lower layer under the mechanical action of the tool pin is strongly agitated so that each layer of the sold joint has the various mechanical properties [18]. The AA2024 was successfully applied with a new welding approach by TIG $\beta$ FSP to improve the mechanical properties of the TIG-welded joints. They find that TIG welding joint defects and porosities are fully reduced by the FSP method and the microstructure and mechanical properties of the welded joint were increased by using of FSP; it has been altered [19] effectively. Using the FSP on the TIG-welded joint, the ductility and the tensile strength of the welding joint AA5083-H112 FSP and TIG were improved [20]. The present study was focused on the improvement of mechanical properties and the residual stress distribution on the welding of aluminum AA8006 alloy in the TIG welding method and optimizing process parameters for obtaining quality weld. 


\section{Materials and Methods}

2.1. Material. In this work, a commercially available aluminium alloy 8006 plate is purchased with the required dimensional plate form characters. Before welding, the bulky AA8006 plate is further cut into $150 \times 50 \times 3 \mathrm{~mm}$ by way of wire-cut EDM. Additionally, it can be finished by a grinding and polishing process [21]. In this study, aluminum alloy 8000 series are taken to investigate the mechanical properties. AA8006 is termed as the wrought alloy. This type of alloy, generally having excellent corrosion prediction nature and having enhanced resistance, also possesses high strength [22]. It is available in foil nature due to its high strength and superior formability. It can be used in the food packing industries, medical equipment manufacturing industries, etc. This investigation used $3 \mathrm{~mm}$ thick AA8006 aluminium alloy plates for experimentation. Tables 1 and 2 present the chemical composition and mechanical properties of AA8006, respectively.

2.2. Taguchi's Design for Experimentation. Usually aluminium alloy welding joints experiments are carried out as per Taguchi method, because Taguchi technique reduces the number of trials and gives optimum results with minimum time and cost [23-26]. The Design of Experiments (DOE) studied by Taguchi by way of orthogonal arrays $(\mathrm{OA})$ is to improve the process parameters affecting the process with different levels [27]. In this examining $L_{9}$ orthogonal array is preferred to play the experimentation and optimize the parameters. Typically, the orthogonal array (OA) degrees of freedom are higher than the total DOF of the parameters [28].

2.3. S/NRatio and ANOVA. In this investigation, Minitab 18 is implemented to examine each control factor's data, and it is evaluated for the mean and S/N ratios [29-31]. All the belongings, on average responses, are symbolized as signals. Computing of deviations is executed by noises from the investigational output. Based on the necessity of elevated strength for the weld joint in this research, the S/N ratio is set as "larger is better" to maximize the output, and the equation evaluating it is

$$
\frac{S}{N}(\eta)=-10 \log _{10}\left\{\frac{1}{n} \sum_{i=1}^{n} \frac{1}{y_{i}^{2}}\right\},
$$

where $y$ is denoting the experiential data and $n$ is termed as the number of trials.

The effects of all the TIG welding parameters of the response (tensile strength, impact strength, and hardness) are identified through statistical methods [32-34]. Each factor's percentage contribution is based on the exact level of confidence, and ANOVA results clearly show the responses' output.

\section{Experiments}

The TIG welding process parameters were selected based on the existing research and the trial experiments conducted for this purpose. The preferred process parameters and their levels are presented in Table 3. The AC power supply type,
Keppi make, $350 \mathrm{~W}$ capacity TIG welding machine were employed for welding these aluminium workpieces.

The nonconsumable tungsten electrode of $3.2 \mathrm{~mm}$ diameter and multicomponent flux AF305 were employed in TIG welding. Constant-current flows of $55 \mathrm{~A}-15 \pm 2 \mathrm{~V}, 60$ $\mathrm{A}-20 \pm 2 \mathrm{~V}$, and $65 \mathrm{~A}-25 \pm 2 \mathrm{~V}$ were utilized to produce arc between AA8006 aluminium alloy plates (work) and electrode in presence of pure argon as shielding gas. The gas flows over the nozzle $(0.125 \mathrm{~m}$ dia); nozzle travel speeds of the $0.14 \mathrm{~m} / \mathrm{min}, 0.15 \mathrm{~m} / \mathrm{min}$, and $0.16 \mathrm{~m} / \mathrm{min}$ were set for experimentation. The arc length was maintained as 0.025 meter long as constant process parameters. Protection of the welding area and the tungsten electrode are achieved by supplying inert gas. The temperature of arc produced in TIG welding process reaches up to $20,000^{\circ} \mathrm{C}$; hence, it is enough to melt aluminium AA8006 metal edges and form the sound weld [35-37]. The welded area can be allowed to solidify for the conversion of the liquid pool into solid nature. Figure 1 illustrates the TIG-welded aluminium alloy 8006 plates effectively.

\section{Characterization for Weld Quality}

4.1. Tensile Strength of TIG-Welded AA8006 Plates. In specimens prepared for tensile test and tested as per ASTM standard ASTM B557-06, the prepared samples and tested specimens are exhibited in Figures 2(a) and 2(b), respectively-the Universal Testing Machine (UTM) under the capacity of $400 \mathrm{kN}$ employed in this investigation. The tensile strengths of the weld on AA8006 plates at various TIG-welding process parameters are presented in Table 4.

4.2. Impact Strength of TIG-Welded AA8006 Plates. During the material's failure, the energy is observed through the impact test identified as impact strength in specimens prepared for tensile test and tested as per ASTM standard ASTM E-23. The prepared samples and tested models are exhibited in Figures 3(a) and 3(b), respectively. All the specimens are fabricated, and the test was executed by using impact testing machine. The test method is termed the Charpy test with the range of 300 J. Figures $4(\mathrm{a})$ and $4(\mathrm{~b})$ show the images of impact test specimens before and after the test were performed. The observations of impact strength of TIG-welded AA8006 plates are furnished in Table 5.

4.3. Surface Hardness of TIG-Welded AA8006 Plates. Hardness is one of the ultimate properties of all materials; a Rockwell hardness testing machine was utilized to perform the welded zone's hardness. The intention selection was achieved based on the material such as aluminum alloy preferably $1 / 16^{\prime \prime}$ hard steel ball applying load of $100 \mathrm{kgf}$. The test was performed in the Rockwell hardness tester; the indentation was marked on the weld bead effectively. The average readings of hardness were taken to estimate the hardness values of all specimens. Figure 5 illustrates the Rockwell hardness testing specimens effectively. The tested surface hardness of TIG-welded AA8006 plates is consolidated and presented in Table 6 . 
Table 1: Chemical elements of AA8006 (wt.\%).

\begin{tabular}{lccccccc}
\hline Material & Magnesium & Manganese & Copper & Iron & Silicon & Zinc & Aluminium \\
\hline AA8006 & 0.10 & 0.90 & 0.30 & 1.5 & 0.40 & 0.10 & Rem. \\
\hline
\end{tabular}

TABLe 2: Properties of 8006 alloys.

\begin{tabular}{lc}
\hline Properties & Metric \\
\hline Density & $2.74 \mathrm{~g} / \mathrm{cm}^{3}$ \\
Elastic modulus & $70 \mathrm{MPa}$ \\
Hardness & $75 \mathrm{HB}$ \\
Thermal conductivity & $200 \mathrm{~W} / \mathrm{mk}$ \\
\hline
\end{tabular}

TABle 3: Process parameters and their levels.

\begin{tabular}{lccccc}
\hline S. no. & Factors (welding parameters) & Unit & Level 1 & Level 2 & 180 \\
\hline 1 & Peak current & Amps & 170 & 190 \\
2 & Base current & Amps & 55 & 60 & 65 \\
3 & Welding speed & $\mathrm{mm} / \mathrm{min}$ & 140 & 150 & 160 \\
\hline
\end{tabular}

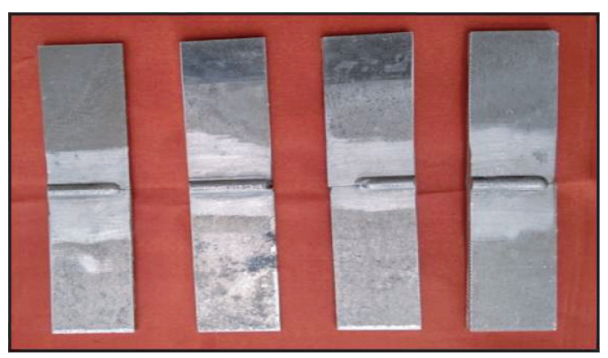

Figure 1: TIG-welded AA8006 plates.
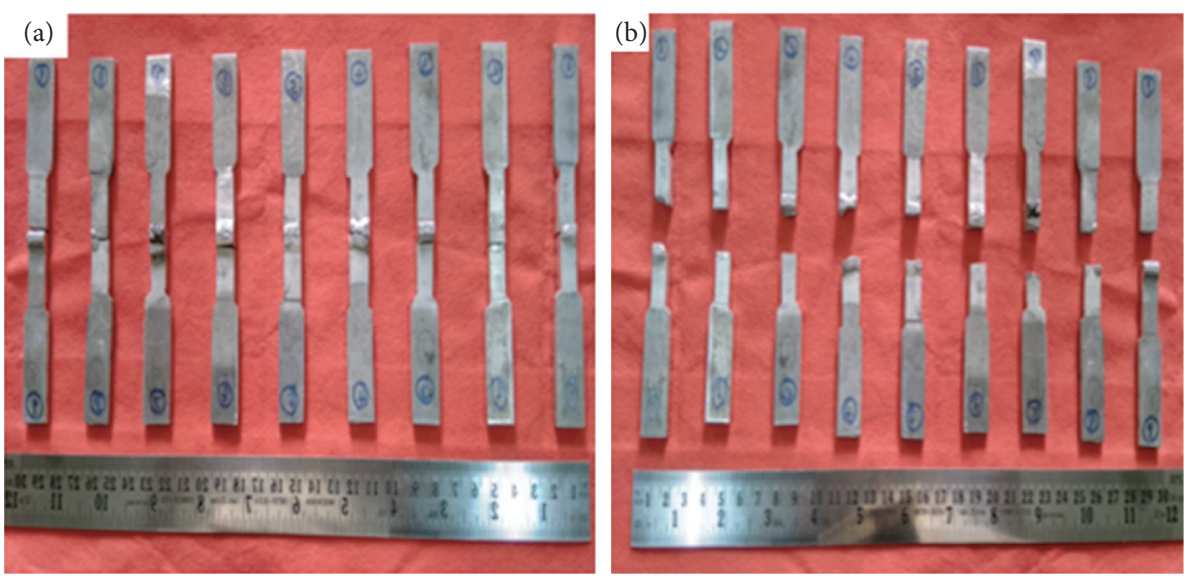

FIGURE 2: Samples prepared and tested in the tensile test: (a) before testing and (b) after testing.

TABle 4: Tensile strength of TIG-welded AA8006 plates.

\begin{tabular}{lcccc}
\hline S. no. & Peak current (Amps) & Base current (Amps) & Welding speed (mm/min) & Tensile strength $(\mathrm{MPa})$ \\
\hline 1 & 170 & 55 & 140 & 109.42 \\
2 & 170 & 60 & 150 & 81.57 \\
3 & 170 & 65 & 160 & 54.83 \\
4 & 180 & 55 & 140 & 97.51 \\
5 & 180 & 60 & 150 & 70.82 \\
6 & 180 & 65 & 160 & 79.18 \\
\hline
\end{tabular}


TABle 4: Continued.

\begin{tabular}{lcccc}
\hline S. no. & Peak current (Amps) & Base current (Amps) & Welding speed $(\mathrm{mm} / \mathrm{min})$ & Tensile strength $(\mathrm{MPa})$ \\
\hline 7 & 190 & 55 & 140 & 86.91 \\
8 & 190 & 60 & 150 & 96.45 \\
9 & 190 & 65 & 160 & 67.59 \\
\hline
\end{tabular}
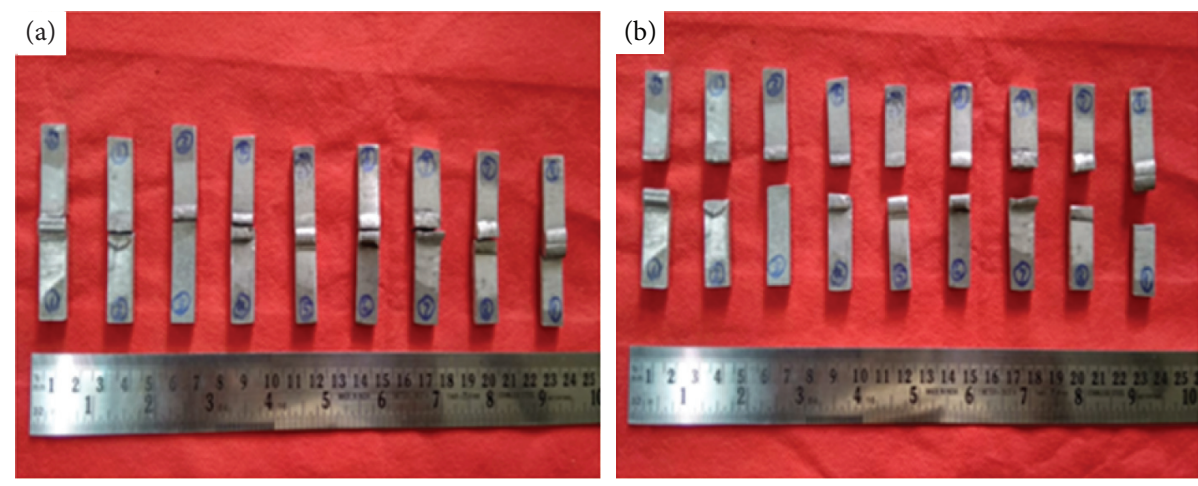

FIgURE 3: Impact test specimens (a) before testing and (b) after testing.
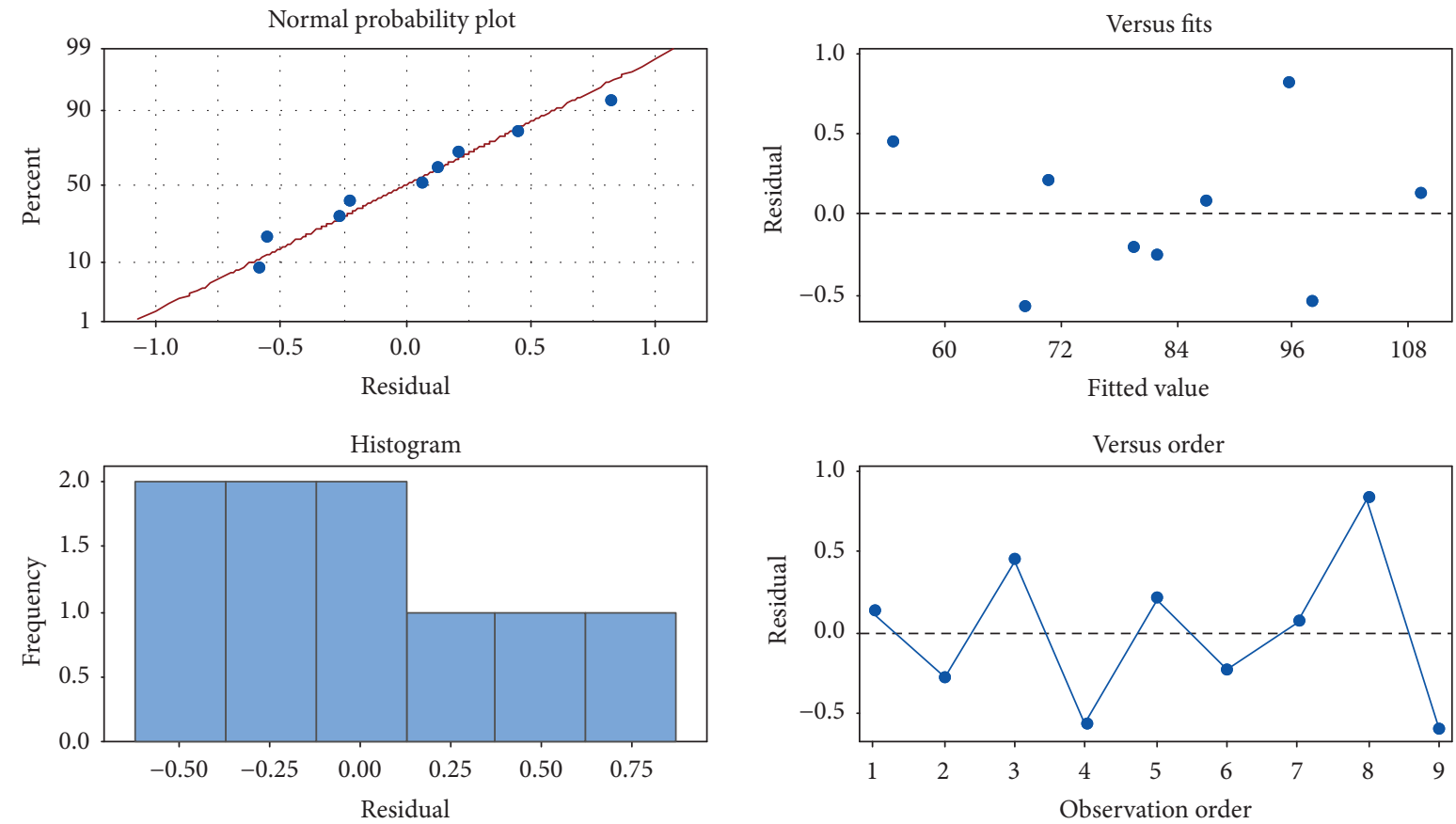

Figure 4: Residual plots for tensile test.

TABLE 5: Impact strength of TIG-welded AA8006 plates.

\begin{tabular}{lcccc}
\hline S. no. & Peak current $($ Amps $)$ & Base current $($ Amps $)$ & Welding speed $(\mathrm{mm} / \mathrm{min})$ & Impact strength $(\mathrm{J})$ \\
\hline 1 & 170 & 55 & 140 & 26 \\
2 & 170 & 60 & 150 & 28 \\
3 & 170 & 65 & 160 & 36 \\
4 & 180 & 55 & 150 & 16 \\
5 & 180 & 60 & 160 & 23 \\
6 & 180 & 65 & 140 & 41 \\
7 & 190 & 55 & 150 & 24 \\
8 & 190 & 60 & 160 & 30 \\
9 & 190 & 65 & & 24 \\
\hline
\end{tabular}




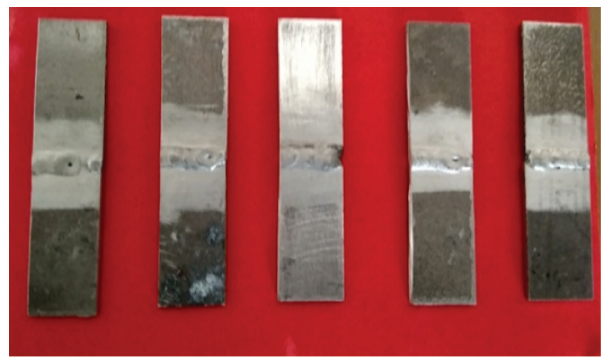

FIgURE 5: Rockwell hardness testing specimen.

TABLE 6: The Rockwell hardness values of TIG-welded AA8006 plates.

\begin{tabular}{lcccc}
\hline S. no. & Peak current (Amps) & Base current (Amps) & Welding speed (mm/min) & Rockwell hardness (HRB) \\
\hline 1 & 170 & 55 & 140 & 26 \\
2 & 170 & 60 & 150 & 28 \\
3 & 170 & 65 & 160 & 36 \\
4 & 180 & 55 & 140 & 16 \\
5 & 180 & 60 & 150 & 23 \\
6 & 180 & 65 & 160 & 41 \\
7 & 190 & 55 & 140 & 12 \\
8 & 190 & 60 & 150 & 24 \\
9 & 190 & 65 & 160 & 30 \\
\hline
\end{tabular}

4.4. Surface Quality of TIG-Welded AA8006 Plates. The surface quality of TIG-welded AA8006 plates is investigated. The SEM images were converted into 3D profilometric photos, and all nine images represented the tensile behavior of each specimen. The images are presented and discussed in the next section.

\section{Results and Discussion}

In this analysis, the tensile strength, impact strength, and hardness values were determined, and they estimated TIG process parameters' effect. Table 7 presents the experimental input value, response, means, and signal-to-noise ratio.

5.1. Tensile Strength. The influence of TIG welding process parameters on the strengths of weld was statistically analyzed by using Minitab 18 software, in which the experimental data are converted into mean and $\mathrm{S} / \mathrm{N}$ ratios to determine the optimal process parameters. The response for means and $\mathrm{SN}$ ratio values is tabulated in Tables 8 and 9, respectively.

From the analysis, the optimum parameter is determined as $\mathrm{PC}_{3} \mathrm{BC}_{1} \mathrm{WS}_{1}$. From Tables 8 and 9 , it is inferred that the most significant parameter concerning tensile strength is base current $\left(\mathrm{BC}_{1}-55 \mathrm{Amps}\right)$, followed by welding speed $\left(\mathrm{WS}_{1}-140 \mathrm{~mm} / \mathrm{min}\right)$ and peak current $\left(\mathrm{PC}_{3}-190 \mathrm{Amps}\right)$. Figures 6 and 7 show the main effect plots for mean and $S / \mathrm{N}$ ratio: the increase of peak current increases the tensile strength, and the 190 Amps peak current offered excellent tensile strength. The $55 \mathrm{Amps}$ and the $140 \mathrm{~mm} / \mathrm{min}$ welding speed provided the maximum tensile strength.

Figure 4 illustrates the residual plots for tensile strength. The four-in-one graph explained well the influence of factors level. The nine samples were reflected in the form of points; all the points are nearer to it; the normal probability plot points out of the maximum points are lying on the mean line since the elected model was exceptional. In the histogram plot, all the rectangular boxes are distributed regularly in a manner. In the observation order, more than $70 \%$ of points are crossed across the line; it notifies that the factor chosen was the very intellectual approach.

The ANOVA is used to examine the significance of the process parameters which affect the responses. The Fisher test (F-test) is also used to investigate the importance of factors that affect the output responses. In this study, among the three elements, the base current has a higher $F$-value, and therefore it is considered to affect the tensile strength. Analysis of variance (ANOVA) of $\mathrm{S} / \mathrm{N}$ ratio for tensile strength is presented in Table 10. Based on the ANOVA results, base current is considered the most significant parameter $(67.66 \%)$, which affects the tensile strength followed by welding speed and peak current. Welding speed contributes $38.08 \%$ and peaks current $0.19 \%$.

Figures 8 (a)-8(c) illustrate the contour plot of tensile strength. The high value of peak current (190 Amps) and the 55 Amps of the base current offer the maximum tensile strength, as shown in Figure 8(a). The 55 Amps base current and $140 \mathrm{~mm} / \mathrm{min}$ welding speed provide the maximum tensile strength shown in Figure 8(b). Figure 8(c) demonstrates the $140 \mathrm{~mm} / \mathrm{min}$ welding speed, and 190 Amps of the peak current induced the maximum tensile strength.

5.2. Impact Strength. Using Minitab, all the investigational data are altered into mean and $\mathrm{S} / \mathrm{N}$ ratios to estimate the optimum process parameters. In this study, the effect of process parameters and levels is determined as $\mathrm{PC}_{1} \mathrm{BC}_{3} \mathrm{WS}_{1}$ and tabulated the means and $\mathrm{SN}$ ratio values in Tables 11 and 12 , respectively. 
TABLE 7: Summary of experimental output values.

\begin{tabular}{|c|c|c|c|c|c|c|c|c|c|}
\hline $\begin{array}{l}\text { S. } \\
\text { no. }\end{array}$ & $\begin{array}{c}\text { Peak } \\
\text { current } \\
\text { (Amps) }\end{array}$ & $\begin{array}{c}\text { Base } \\
\text { current } \\
\text { (Amps) }\end{array}$ & $\begin{array}{l}\text { Welding speed } \\
(\mathrm{mm} / \mathrm{min})\end{array}$ & $\begin{array}{c}\text { Tensile } \\
\text { strength } \\
(\mathrm{MPa})\end{array}$ & $\begin{array}{c}\text { Impact } \\
\text { strength }(\mathrm{J})\end{array}$ & $\begin{array}{c}\text { Hardness } \\
\text { (HRB) }\end{array}$ & $\begin{array}{c}\text { SN ratio of } \\
\text { tensile } \\
\text { strength }\end{array}$ & $\begin{array}{c}\text { SN ratio of } \\
\text { impact } \\
\text { strength }\end{array}$ & $\begin{array}{c}\text { SN ratio of } \\
\text { hardness } \\
(\mathrm{HRB})\end{array}$ \\
\hline 1 & 170 & 55 & 140 & 109.42 & 26 & 42 & 40.781 & 28.299 & 32.465 \\
\hline 2 & 170 & 60 & 150 & 81.57 & 28 & 35 & 38.230 & 28.943 & 31.126 \\
\hline 3 & 170 & 65 & 160 & 54.83 & 36 & 28 & 34.780 & 31.126 & 28.943 \\
\hline 4 & 180 & 55 & 140 & 97.51 & 16 & 48 & 39.781 & 24.082 & 33.624 \\
\hline 5 & 180 & 60 & 150 & 70.82 & 23 & 44 & 37.003 & 27.234 & 32.869 \\
\hline 6 & 180 & 65 & 160 & 79.18 & 41 & 26 & 37.972 & 32.255 & 28.299 \\
\hline 7 & 190 & 55 & 140 & 86.91 & 12 & 52 & 38.781 & 21.583 & 34.320 \\
\hline 8 & 190 & 60 & 150 & 96.45 & 24 & 38 & 39.686 & 27.604 & 31.595 \\
\hline 9 & 190 & 65 & 160 & 67.59 & 30 & 36 & 36.597 & 29.542 & 31.126 \\
\hline
\end{tabular}

TABLE 8: Response table for tensile strength means (larger is better).

\begin{tabular}{lccc}
\hline Level & Peak current (Amps) & Base current $($ Amps $)$ & Welding speed (mm/min) \\
\hline 1 & 81.94 & 97.95 & 95.02 \\
2 & 82.50 & 82.95 & 82.22 \\
3 & 83.65 & 67.20 & 70.85 \\
Delta & 1.71 & 30.75 & 24.16 \\
Rank & 3 & 1 & 2 \\
\hline
\end{tabular}

TABle 9: Response table for $\mathrm{S} / \mathrm{N}$ ratio (tensile strength) (larger is better).

\begin{tabular}{lccc}
\hline Level & Peak current (Amps) & Base current (Amps) & Welding speed (mm/min) \\
\hline 1 & 37.93 & 39.78 & 39.48 \\
2 & 38.25 & 38.31 & 38.20 \\
3 & 38.36 & 36.45 & 36.85 \\
Delta & 0.42 & 3.33 & 2.63 \\
Rank & 3 & 1 & 2 \\
\hline
\end{tabular}

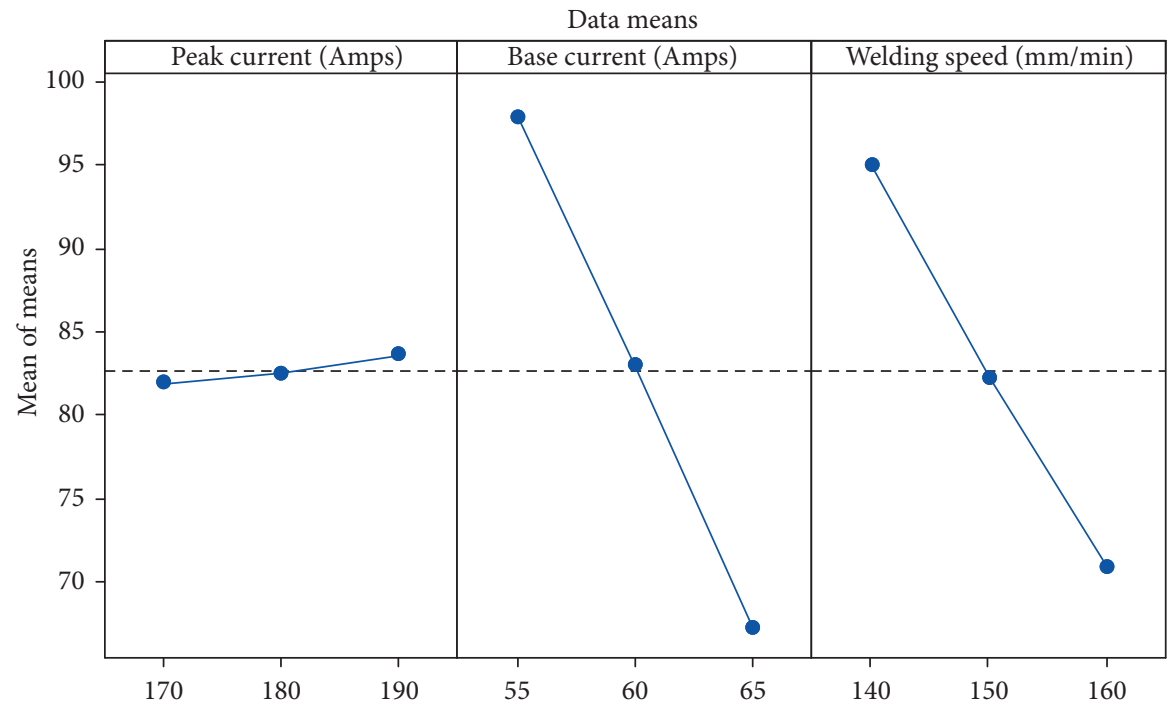

Figure 6: Main effect plot for the tensile strength means.

Figures 9 and 10 show the main effects plot for means and the main effects plot for SN ratios. The maximum impact strength was obtained as per the involvement of $170 \mathrm{Amps}$ peak current, and increasing peak current decreases the impact strength. Increasing of base current increases the impact strength, as well as the 65 Amps of the base current, offering excellent impact strength. The welding speed of $140 \mathrm{~mm} / \mathrm{min}$ produces the maximum impact strength. 


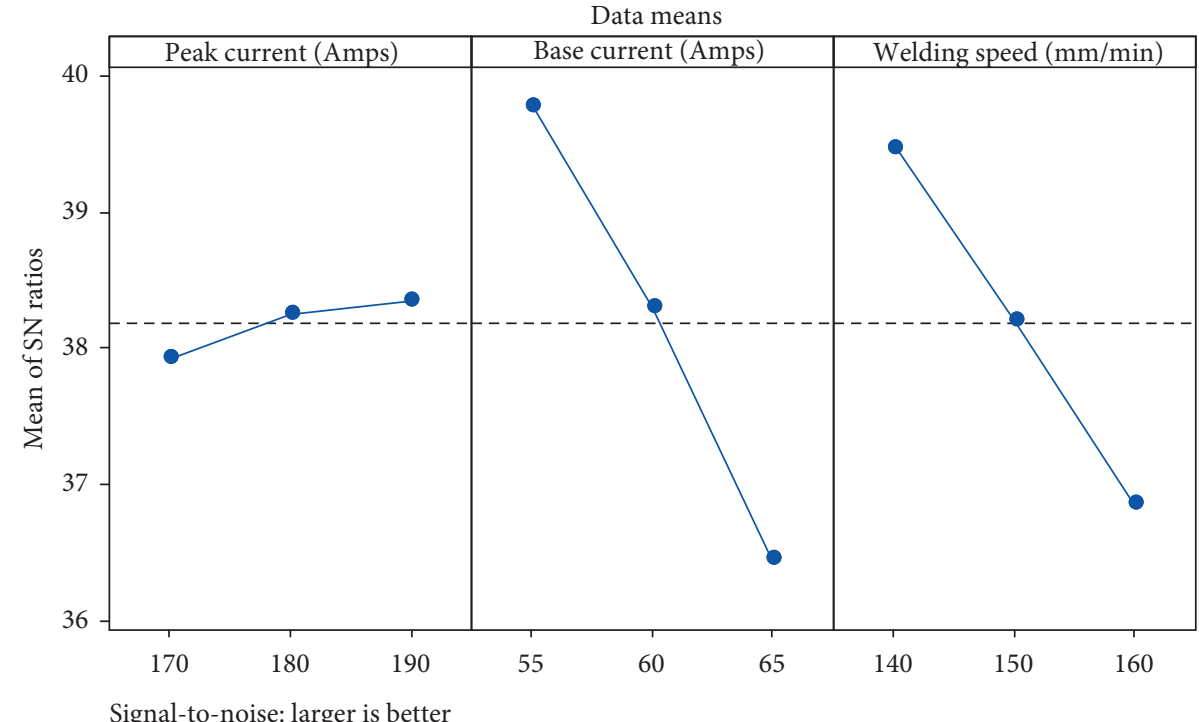

Figure 7: Main effect plot for S/N ratios.

TABLE 10: Analysis of variance for the regression model ( $\mathrm{S} / \mathrm{N}$ ratio-tensile strength).

\begin{tabular}{|c|c|c|c|c|c|c|c|}
\hline Source & $\mathrm{DF}$ & Seq SS & Contribution (\%) & Adj SS & Adj MS & $F$-value & $P$ value \\
\hline Regression & 3 & 2298.22 & 99.93 & 2298.22 & 766.07 & 2240.8 & $\leq 0.001$ \\
\hline Peak current (Amps) & 1 & 4.39 & 0.19 & 4.39 & 4.39 & 12.83 & 0.016 \\
\hline Base current (Amps) & 1 & 1418.04 & 61.66 & 1418.04 & 1418.04 & 4147.9 & $\leq 0.001$ \\
\hline Welding speed $(\mathrm{mm} / \mathrm{min})$ & 1 & 875.80 & 38.08 & 875.80 & 875.80 & 2561.8 & $\leq 0.001$ \\
\hline Error & 5 & 1.71 & 0.07 & 1.71 & 0.34 & & \\
\hline Total & 8 & 2299.93 & 100.00 & & & & \\
\hline
\end{tabular}

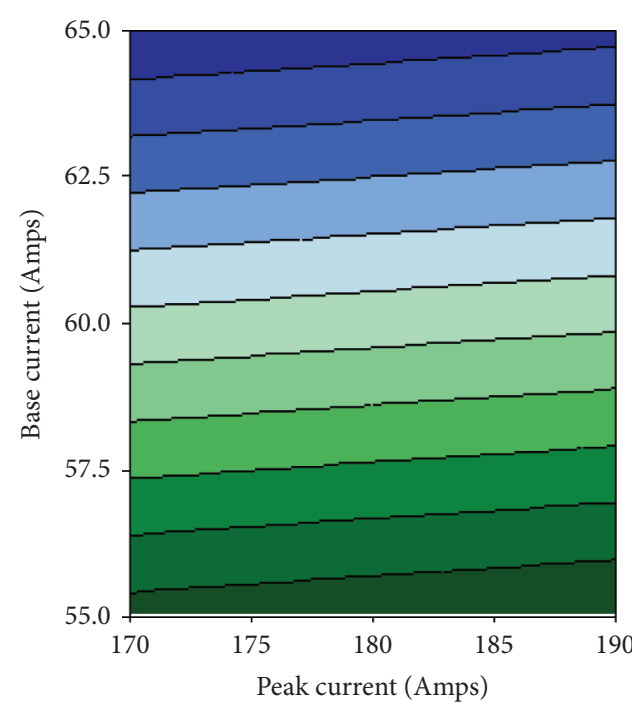

(a)

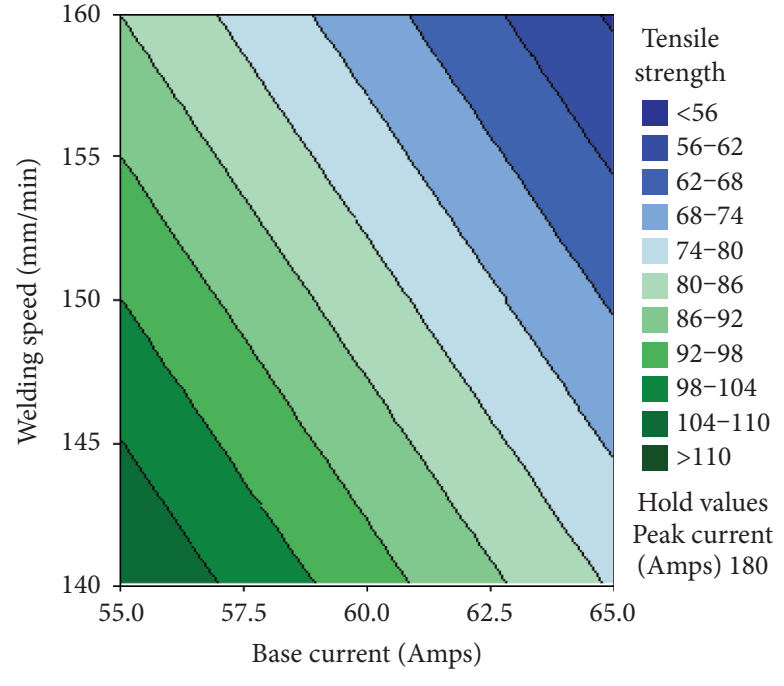

(b)

Figure 8: Continued. 


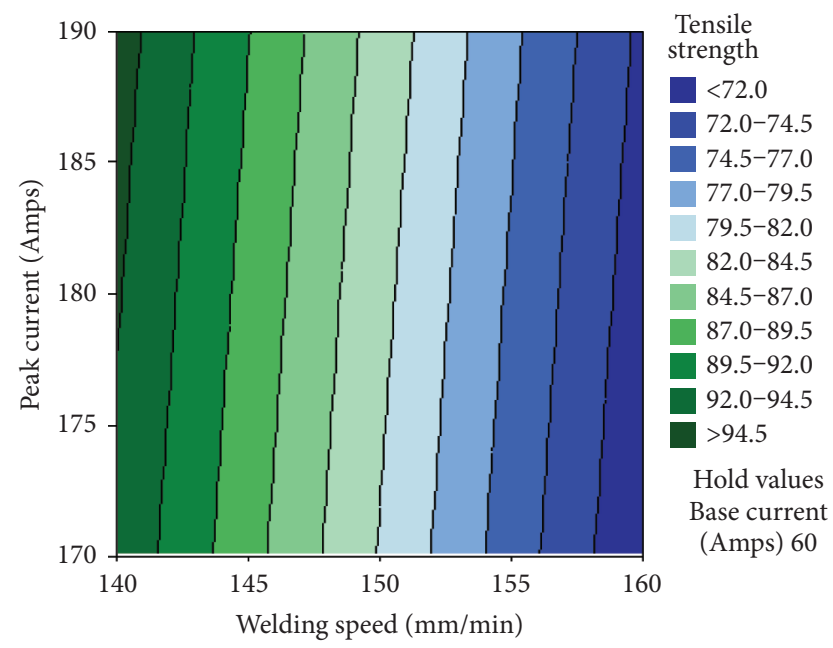

(c)

FIgURE 8: (a) Contour plot of tensile strength with respect to peak current and base current. (b) Contour plot of tensile strength with respect to base current and welding speed. (c) Contour plot of tensile vs. welding speed and peak current.

TABLE 11: Response table for means (impact strength) (larger is better).

\begin{tabular}{lccc}
\hline Level & Peak current (Amps) & Base current (Amps) & Welding speed (mm/min) \\
\hline 1 & 30.00 & 18.00 & 30.33 \\
2 & 26.67 & 25.00 & 24.67 \\
3 & 22.00 & 35.67 & 23.67 \\
Delta & 8.00 & 17.67 & 6.67 \\
Rank & 2 & 1 & 3 \\
\hline
\end{tabular}

TABLE 12: Response table for S/N ratios (impact strength) (larger is better).

\begin{tabular}{lccc}
\hline Level & Peak current (Amps) & Base current (Amps) & Welding speed (mm/min) \\
\hline 1 & 29.46 & 24.66 & 29.39 \\
2 & 27.86 & 27.93 & 27.52 \\
3 & 26.24 & 30.97 & 26.65 \\
Delta & 3.21 & 6.32 & 2.74 \\
Rank & 2 & 1 & 3 \\
\hline
\end{tabular}

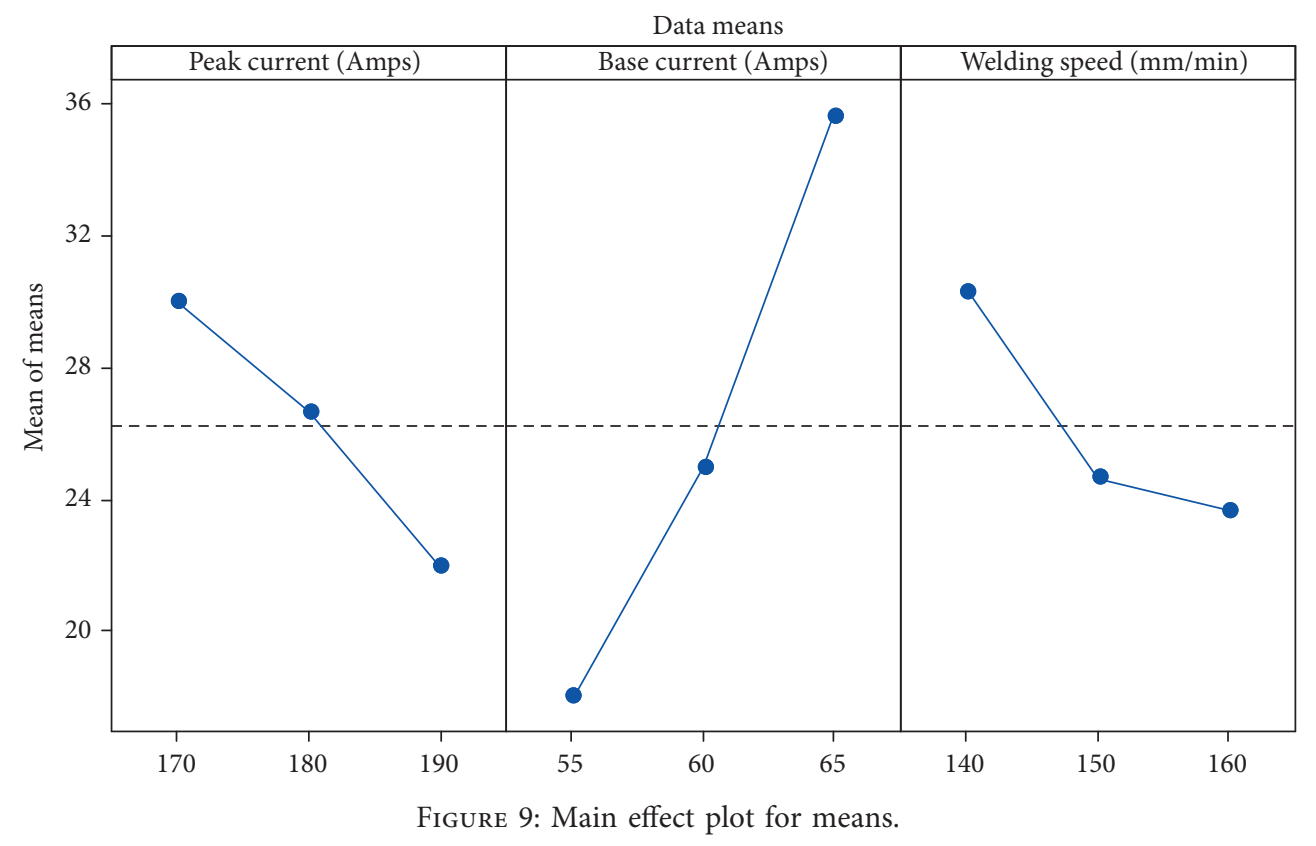




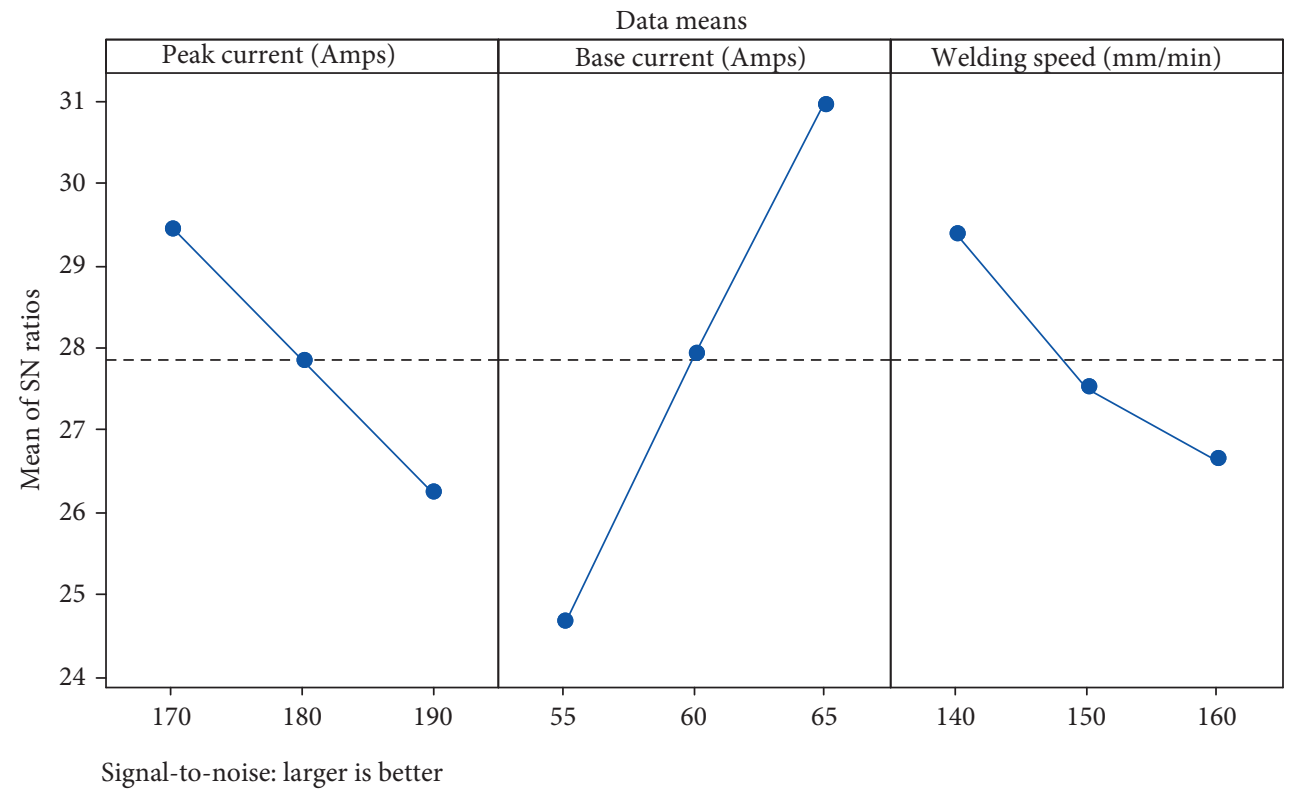

FIgURE 10: Main effect plot for S/N ratios.

Figure 11 illustrates the residual plots for impact strength, from the four-in-one graph elucidated fine for influencing factors level. All nine samples were tested, and the results were reflected in the form of graphical representation. In this plot, all the points are closer to it; the normal probability plot noticed the maximum issues lying on the mean line since the designated model was incomparable. From the histogram plot, all the rectangular boxes are distributed as standard in mode.

The Fisher test (F-test) is used to study which factors affect the output responses. In this work, among the three parameters, base current has a higher $F$-value, and therefore, it is considered to have effects on the impact strength. Analysis of variance (ANOVA) of $\mathrm{S} / \mathrm{N}$ ratio for impact strength is presented in Table 13. The base current is considered the most significant parameter $(71.63 \%)$ from the ANOVA outcome, affecting the impact strength followed by peak current $14.69 \%$ and welding speed $10.20 \%$.

Figures 12(a)-12(c) show the contour plot of impact strength directly influencing two parameters. The maximum impact strength is obtained by the interaction of high base current and low peak current, high base current and low welding speed, and low welding speed and peak current.

5.3. Hardness Test. From the hardness test, the input parameters rank and its effects are studied through Minitab, and all the investigational data are translated into mean and $\mathrm{S} / \mathrm{N}$ ratios value. The response for means and $\mathrm{SN}$ ratio values are tabulated in Tables 14 and 15, respectively.

The tables visibly identified the key parameters in this study. The base current has highly influenced this analysis, followed by peak current and welding speed based on the delta value and rank order. The hardness test's optimal parameters were obtained as peak current of $190 \mathrm{Amps}$, the base current of 55 Amps, and welding speed of $160 \mathrm{~mm} / \mathrm{min}$.
Figures 13 and 14 show the main effect plot for mean and main effect plot for $\mathrm{S} / \mathrm{N}$ ratio, respectively. The increasing peak current increases the hardness value; applying 190 Amps provided the maximum hardness value. The minimum base current of $55 \mathrm{Amps}$ offered the maximum hardness value; increasing base current reduces the hardness value. Increasing the welding speed from $140 \mathrm{~mm} / \mathrm{min}$ to $160 \mathrm{~mm} / \mathrm{min}$ would increase the hardness value.

Figure 15 presents the residual plots for hardness test; this four-in-one graph enlightens the parameters influencing it in different form. Each sample input and output value were tested and obtained; the results were replicated in the graph. From this plot, all the points are very close to the mean line. It would be noted in the probability plot versus fit graph. In the histogram plot, all the rectangular boxes' values are distributed evenly in the standard one.

From the ANOVA, significant parameter values are analyzed through the Fisher test ( $F$-test); $F$-test was also used to inspect the influential factors which affect the output responses. From this study, among three aspects, the base current has a higher $F$-value. Therefore, it is considered to be an affecting factor of the hardness. Analysis of variance of $\mathrm{S} /$ $\mathrm{N}$ ratio for hardness test is presented in Table 16. The base current is highly contributed from the ANOVA results, such as $76.01 \%$, which affect the hardness followed by the peak current $11.24 \%$, and welding speed contributes $9.11 \%$. The $P$ value of the base current was 0.001 ; it was within the limit of 0.005 .

Figure 16(a) illustrates the contour plot of hardness vs. peak current and base current; the maximum hardness was obtained as the involvement of peak current of 190 Amps and the base current of above 55 Amps. The lowest peak current value and the highest base current value offered minimum hardness value. Figure 16(b) quickly found out the minimum and maximum hardness value, the low base current, and high welding speed as $160 \mathrm{~mm} / \mathrm{min}$ 

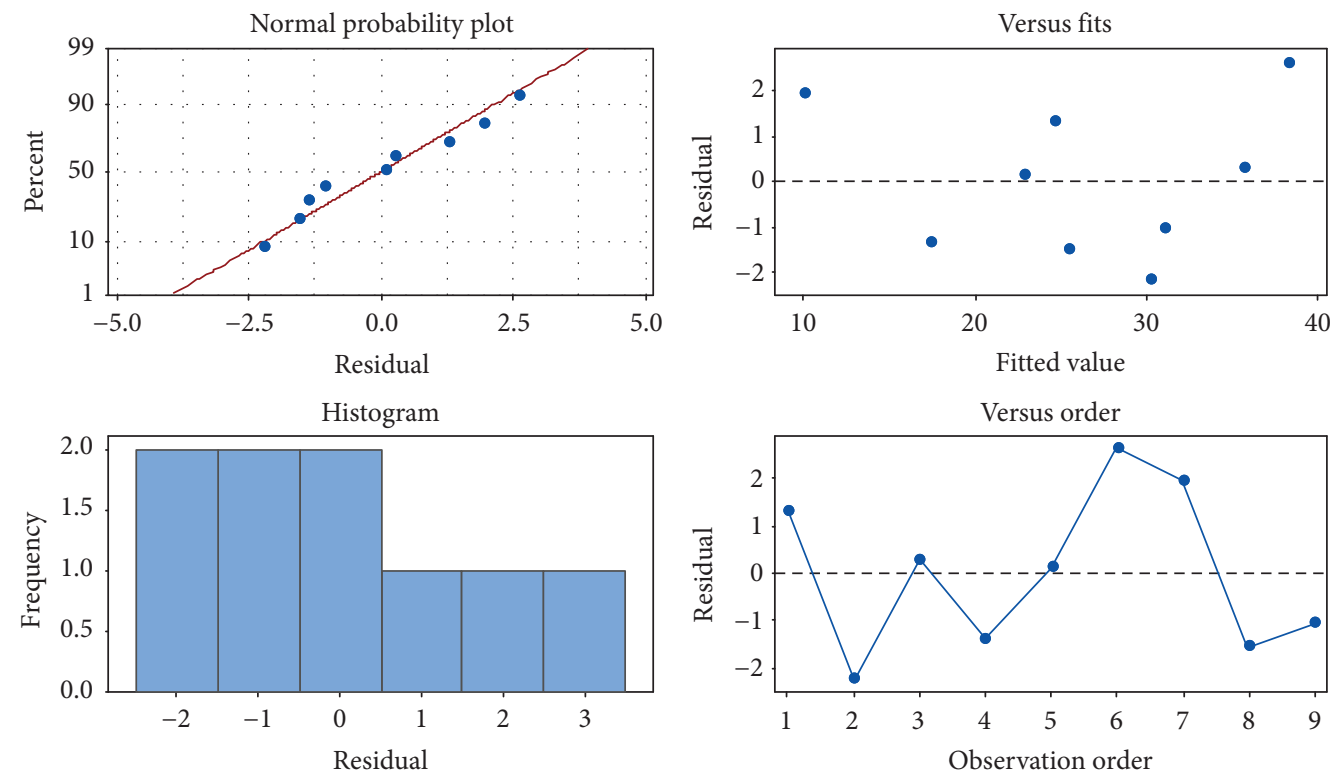

FIgURe 11: Residual plots for impact test.

TABLE 13: Analysis of variance for regression model ( $\mathrm{S} / \mathrm{N}$ ratio-impact strength).

\begin{tabular}{|c|c|c|c|c|c|c|c|}
\hline Source & DF & Seq SS & Contribution (\%) & Adj SS & Adj MS & $F$-value & $P$ value \\
\hline Regression & 3 & 630.83 & 96.52 & 630.83 & 210.278 & 46.27 & $\leq 0.001$ \\
\hline Peak current (Amps) & 1 & 96.00 & 14.69 & 96.00 & 96.000 & 21.12 & 0.006 \\
\hline Base current (Amps) & 1 & 468.17 & 71.63 & 468.17 & 468.167 & 103.02 & $\leq 0.001$ \\
\hline Welding speed $(\mathrm{mm} / \mathrm{min})$ & 1 & 66.67 & 10.20 & 66.67 & 66.667 & 14.67 & 0.012 \\
\hline Error & 5 & 22.72 & 3.48 & 22.72 & 4.544 & & \\
\hline Total & 8 & 653.56 & 100.00 & & & & \\
\hline
\end{tabular}

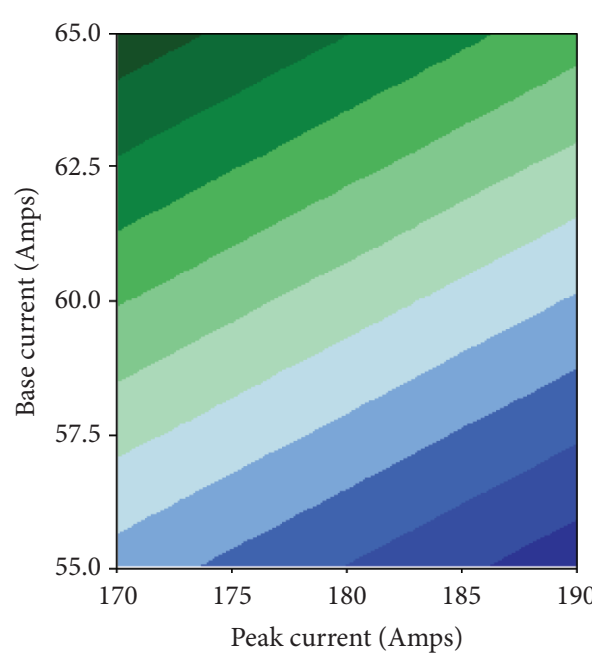

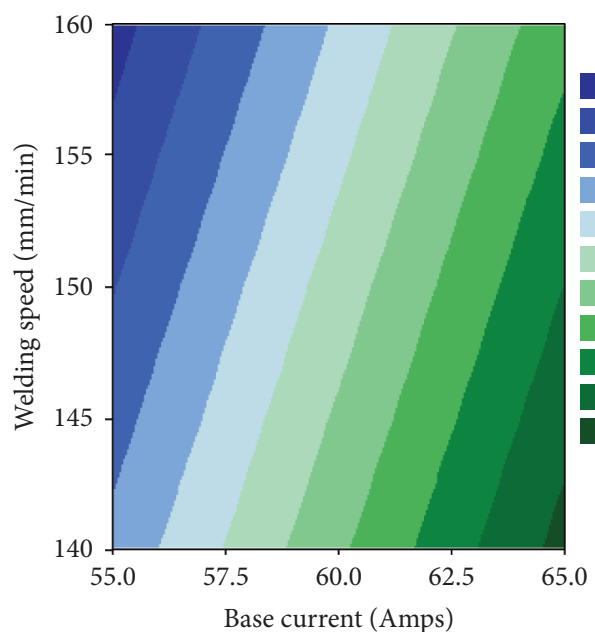

Impact strength (J)

$<15.0$

$15.0-17.5$

$17.5-20.0$

$20.0-22.5$

$22.5-25.0$

$25.0-27.5$

$27.5-30.0$

$30.0-32.5$

$32.5-35.0$

$35.0-37.5$

$>37.5$

Hold values Peak current (Amps) 180
Hold values Welding speed

( $\mathrm{mm} / \mathrm{min}) 150$ (a)

\begin{abstract}
Peak current (Amps)
\end{abstract}
(b)

FIgure 12: Continued. 


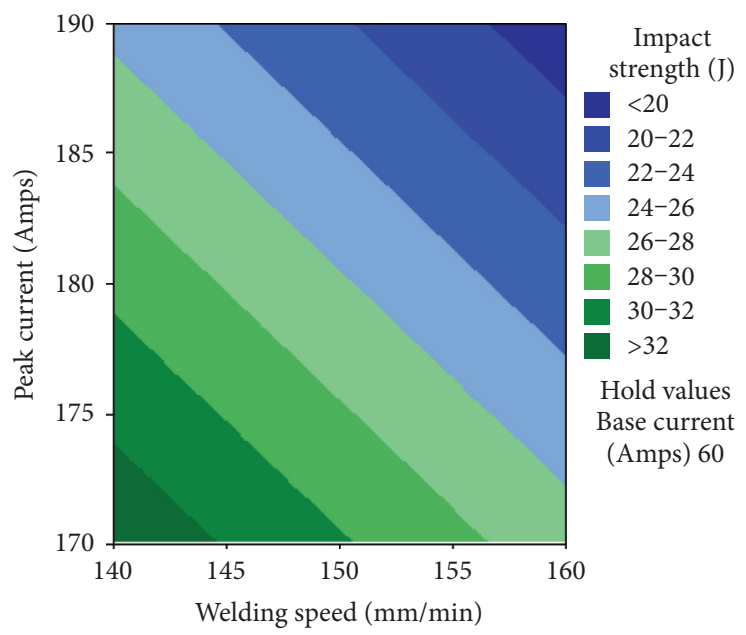

(c)

FIgURE 12: (a) Contour plot of impact peak current and base current. (b) Contour plot of impact base current and welding speed. (c) Contour plot of impact vs. welding speed and peak current.

TABLE 14: Response table for means (hardness) (larger is better).

\begin{tabular}{lccc}
\hline Level & Peak current (Amps) & Base current (Amps) & Welding speed (mm/min) \\
\hline 1 & 35.33 & 47.33 & 35.33 \\
2 & 39.33 & 39.33 & 40.00 \\
3 & 42.00 & 30.00 & 41.33 \\
Delta & 6.67 & 17.33 & 6.00 \\
Rank & 2 & 1 & 3 \\
\hline
\end{tabular}

TABLE 15: Response table for $\mathrm{S} / \mathrm{N}$ ratios (hardness) (larger is better).

\begin{tabular}{lccc}
\hline Level & Peak current (Amps) & Base current (Amps) & Welding speed (mm/min) \\
\hline 1 & 30.84 & 33.47 & 30.79 \\
2 & 31.60 & 31.86 & 31.96 \\
3 & 32.35 & 29.46 & 32.04 \\
Delta & 1.50 & 4.01 & 1.26 \\
Rank & 2 & 1 & 3 \\
\hline
\end{tabular}

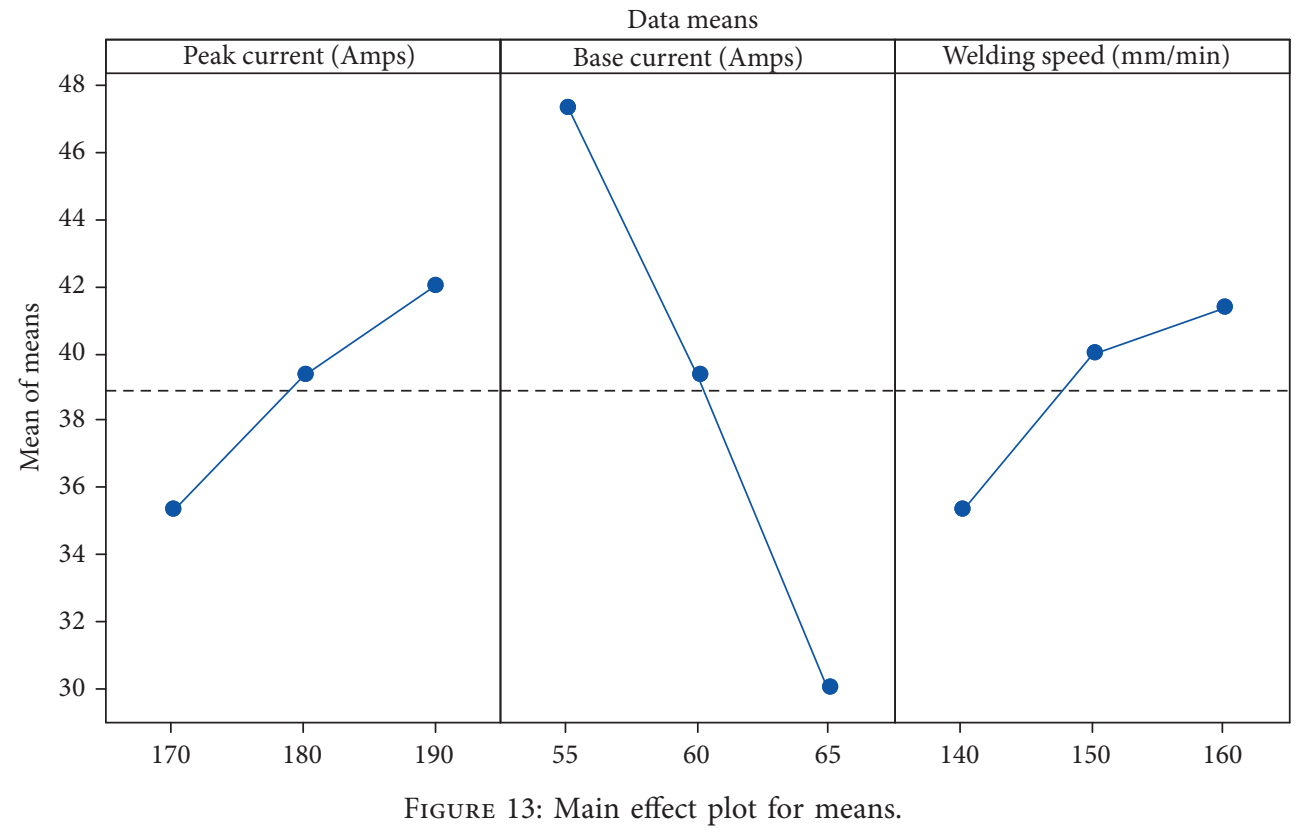




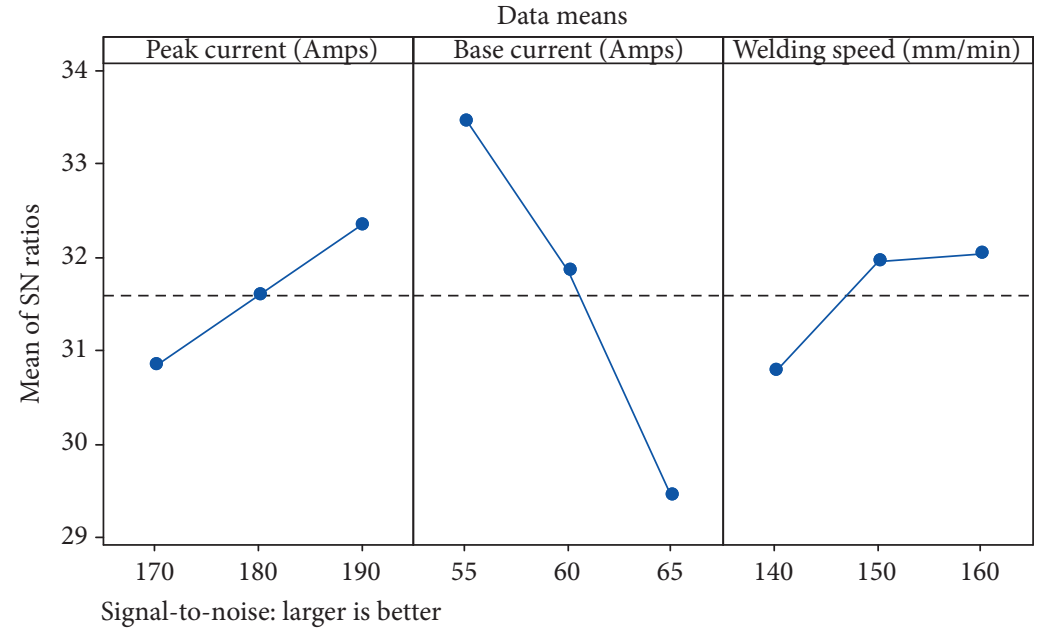

Figure 14: Main effect plot for S/N ratios.
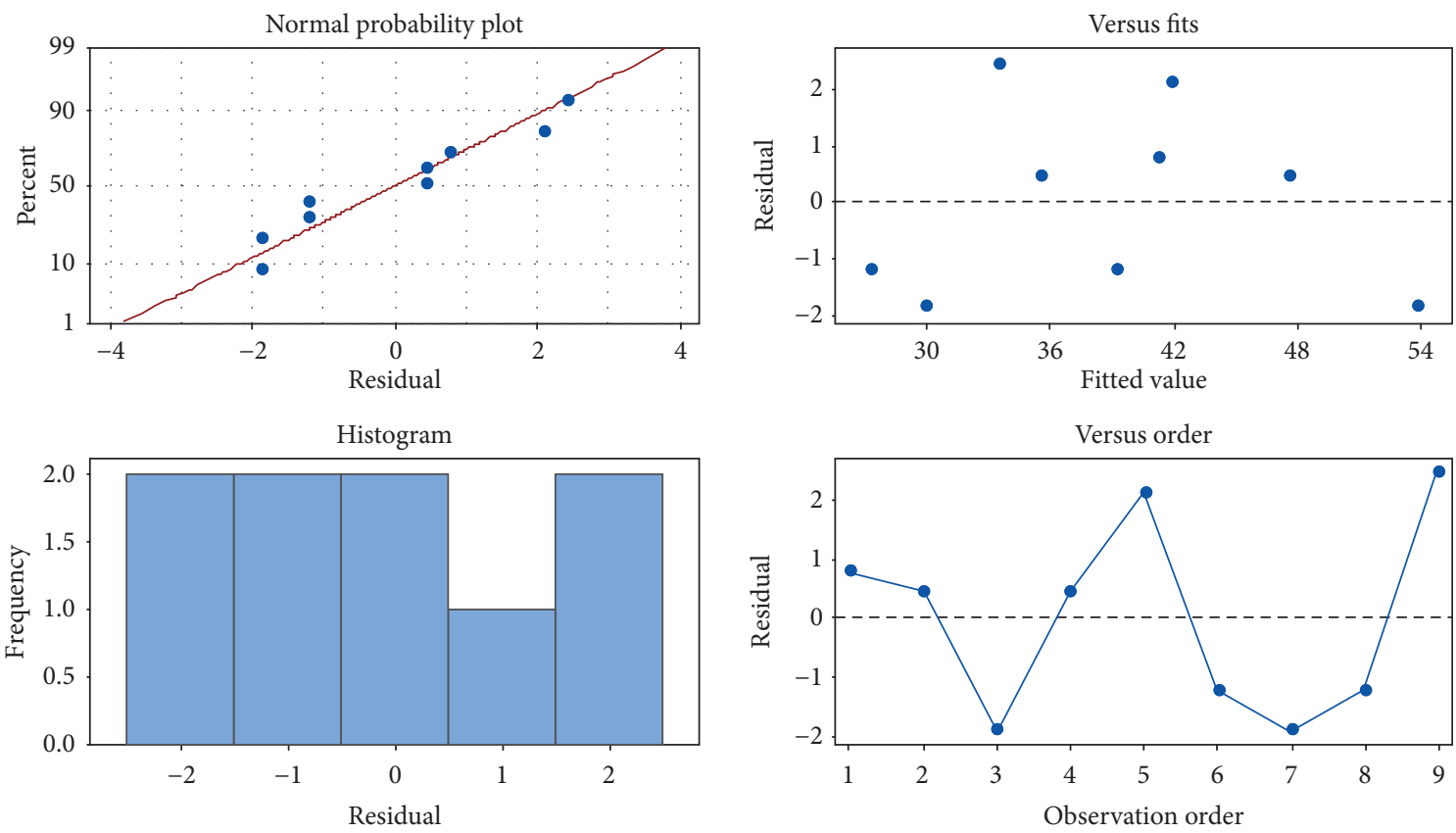

Figure 15: Residual plots for hardness test.

TABle 16: Analysis of variance for regression model (S/N ratio-hardness).

\begin{tabular}{|c|c|c|c|c|c|c|c|}
\hline Source & DF & Seq SS & Contribution (\%) & Adj SS & Adj MS & $F$-value & $P$ value \\
\hline Regression & 3 & 571.33 & 96.36 & 571.33 & 190.444 & 44.18 & 0.001 \\
\hline Peak current (Amps) & 1 & 66.67 & 11.24 & 66.67 & 66.667 & 15.46 & 0.011 \\
\hline Base current (Amps) & 1 & 450.67 & 76.01 & 450.67 & 450.667 & 104.54 & $\leq 0.001$ \\
\hline Welding speed $(\mathrm{mm} / \mathrm{min})$ & 1 & 54.00 & 9.11 & 54.00 & 54.000 & 12.53 & 0.017 \\
\hline Error & 5 & 21.56 & 3.64 & 21.56 & 4.311 & & \\
\hline Total & 8 & 592.89 & 100.00 & & & & \\
\hline
\end{tabular}

recommending the maximum hardness value. The most negligible welding speed and the 65 Amps base current provided the minimum hardness. Figure 16(c) explained the interaction of the contour plot of hardness vs. welding speed and base current. The maximum welding speed of $160 \mathrm{~mm} /$ min and the high peak current of 190 Amps offered outstanding hardness value. The decrease of welding speed and the peak current produces the minimum hardness.

5.4. Surface Quality Investigation. Figures 17(a) to 17(i) illustrate the $3 \mathrm{D}$ profilometric images of the nine tensile tested specimens (as per experiment order), which were obtained by 


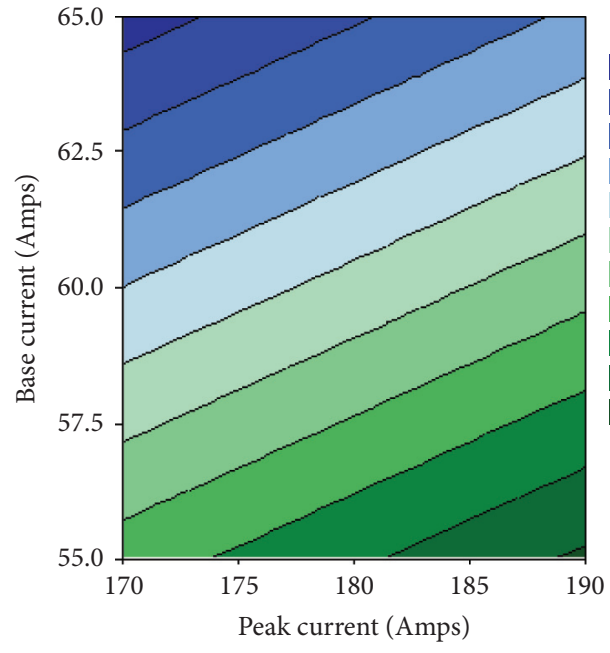

(a)

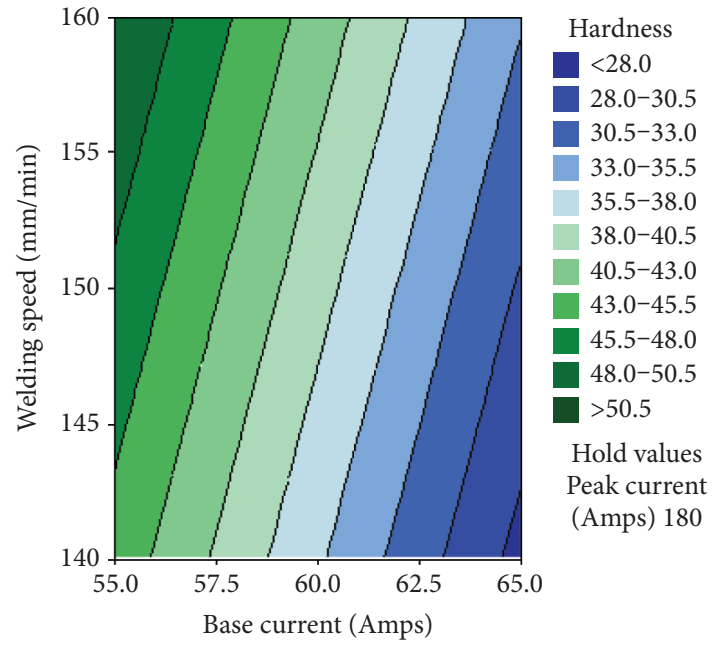

(b)

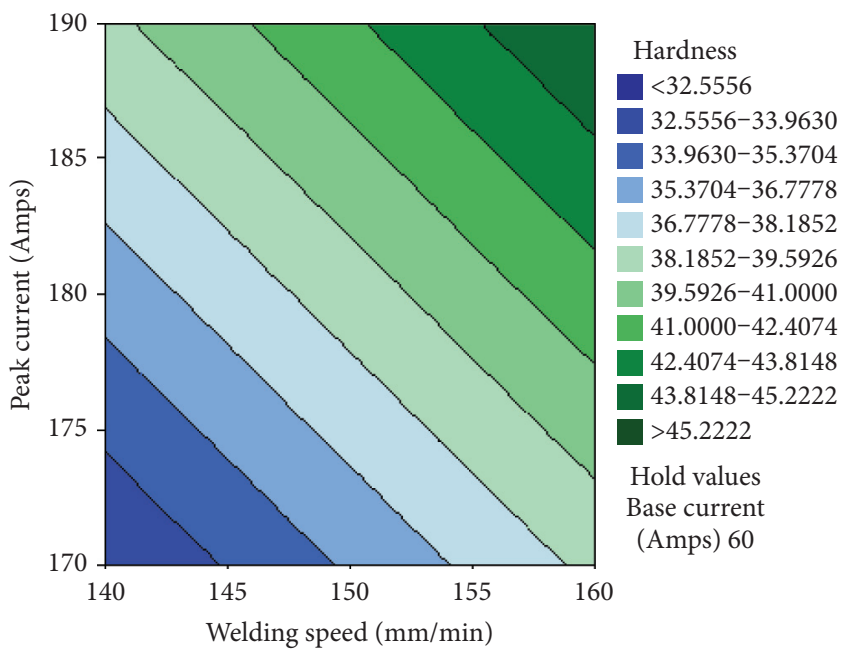

(c)

FIgURE 16: (a) Contour plot of hardness vs. peak current. (b) Contour plot of hardness vs. peak current, base current, and welding speed. (c) Contour plot of hardness vs. welding speed and peak current.

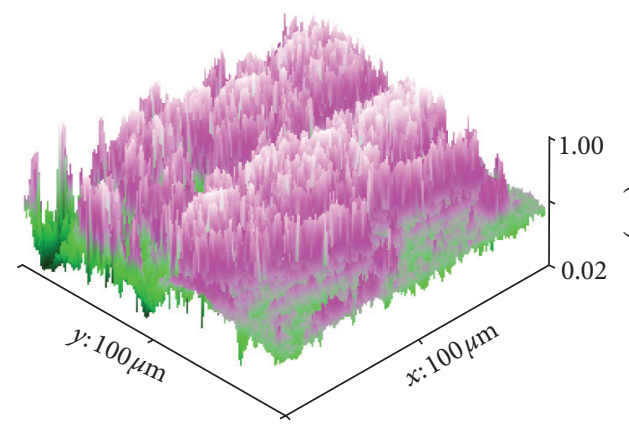

(a)

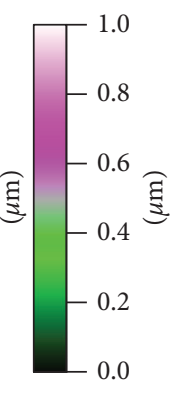

FIgURE 17: Continued.

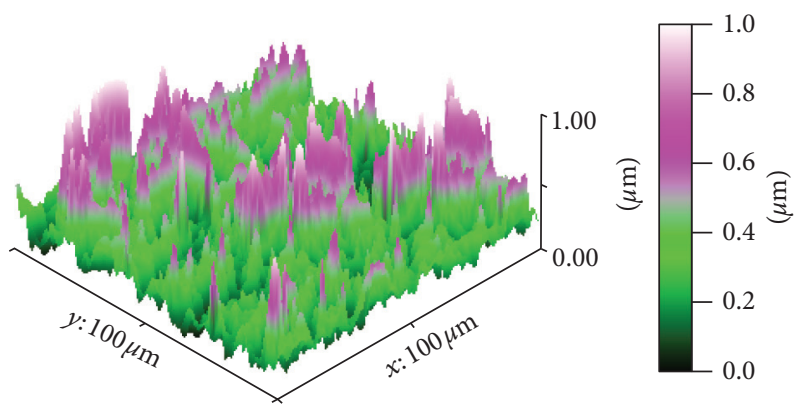

(b) 


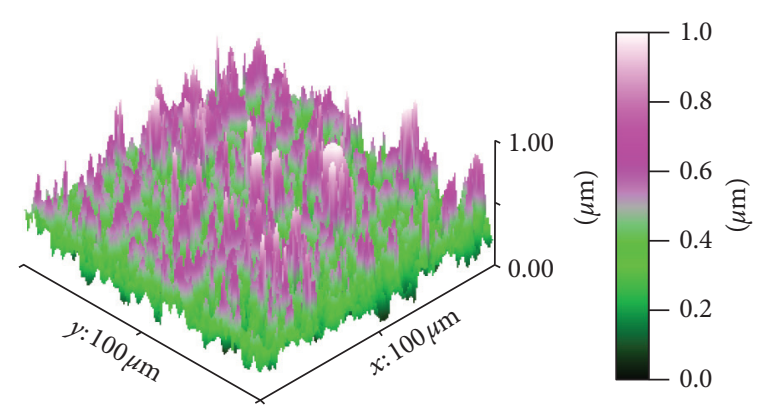

(c)

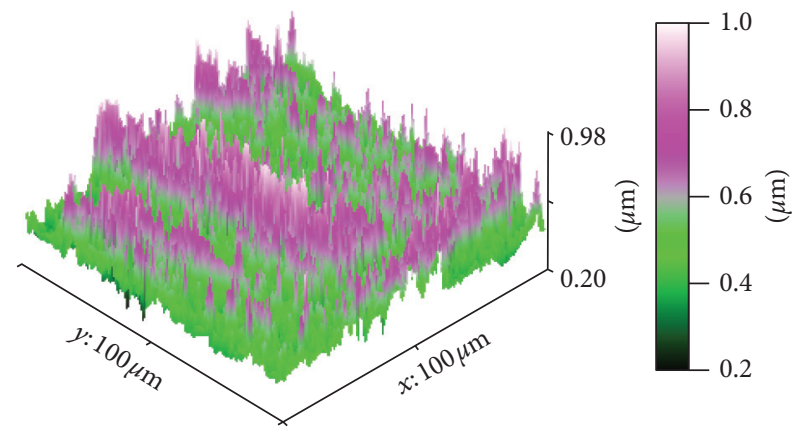

(e)

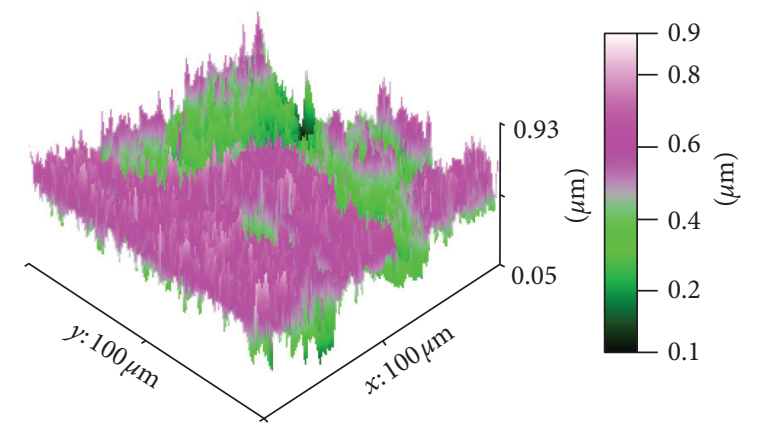

(g)

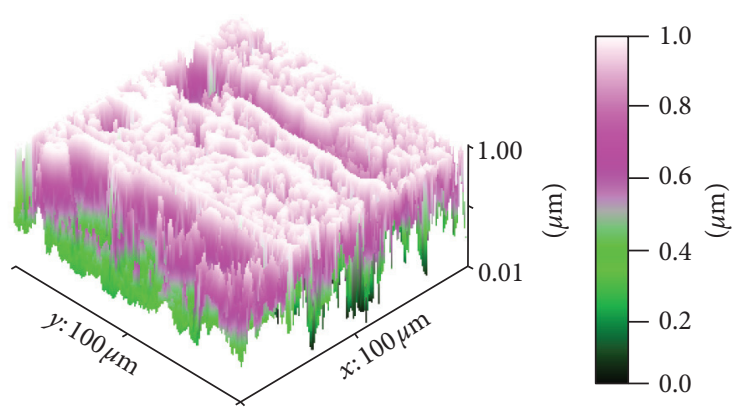

(d)

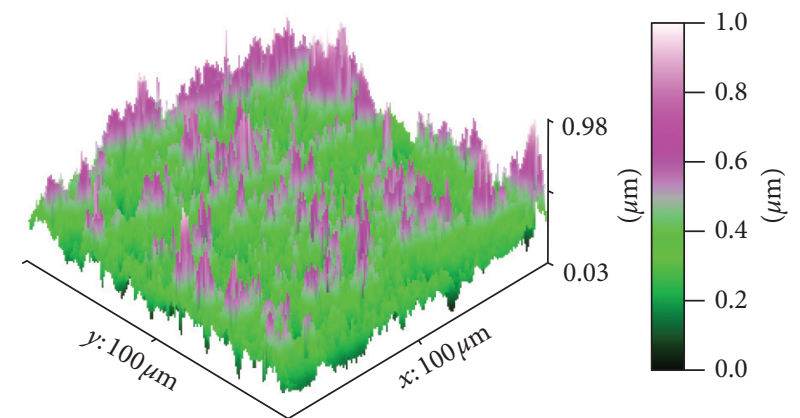

(f)

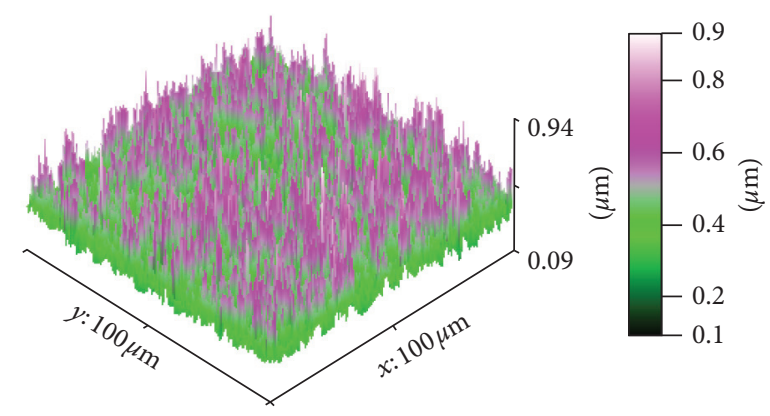

(h)

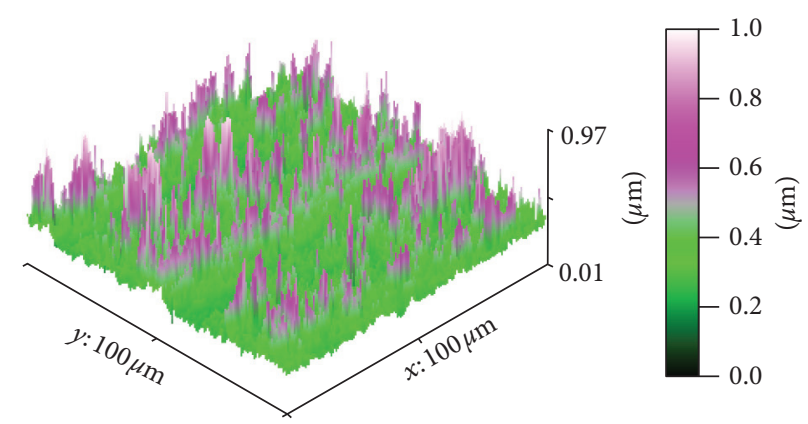

(i)

FIGURE 17: 3D profilometric images of the tensile test specimen as per experiment order.

conversion of SEM images into 3D profilometric images. All nine images represented the tensile behavior of each specimen. In Figure 17, each image is filled with two different colours like pink and green. Where the pink colour is noticed, the welded area possesses high denser material formation to avoid the material's tensile failure and also demonstrates the welding strength [38]. The green colour indicated the place of the weaker section of the material at which the material weld has low density and low tensile strength. According to this, in Figures 17(a) and $17(d)$, samples were welded strongly more than the other 7 samples. Hence the dense pack of weld material could be achieved by means of input parameters utilized for first and fourth sample welding. 


\section{Conclusions}

The experimental investigation of AA8006 TIG welding was carried out fruitfully. Mechanical properties such as Rockwell hardness, impact strength, and tensile strength were estimated with influence of chosen parameters, and the result of this investigation was concluded as follows:

(i) The optimum parameter is determined from the tensile test analysis as $\mathrm{PC}_{3} \mathrm{BC}_{1} \mathrm{WS}_{1}$, and the optimal values are base current 55 Amps, followed by welding speed $140 \mathrm{~mm} / \mathrm{min}$ and peak current 190 Amps. From the ANOVA results, the base current is considered the most significant parameter, and its contribution is $67.66 \%$, further followed by welding speed and peak current of $38.08 \%$ and $0.19 \%$, respectively.

(ii) In the impact strength, the optimal parameters were attained as $\mathrm{PC}_{1} \mathrm{BC}_{3} \mathrm{WS}_{1}$, and its values were peak current of 170 Amps, base current of 65 Amps, and the welding speed of $140 \mathrm{~mm} / \mathrm{min}$. From the ANOVA conclusion, the base current is considered the most significant parameter. Its contribution is $71.63 \%$, which affects the impact next, followed by a peak current of $14.69 \%$ and finally welding speed of $10.20 \%$.

(iii) In this study, the effect of process parameters and optimal values was determined as $\mathrm{PC}_{3} \mathrm{BC}_{1} \mathrm{WS}_{3}$. The result of optimal values is the peak current of 190 Amps, the base current of 55 Amps, and a welding speed of $160 \mathrm{~mm} / \mathrm{min}$. The base current is highly contributed in the ANOVA results, such as $76.01 \%$, followed by peak current contributed as $11.24 \%$ and welding speed $9.11 \%$.

(iv) In all tests, the base current has a prime factor in the tensile, impact, and hardness test. Experimental values of maximum tensile strength were obtained as $109.42 \mathrm{MPa}$, impact strength was $41 \mathrm{~J}$, and hardness value was $52 \mathrm{HRB}$.

\section{Abbreviations}

TIG: Tungsten inert gas

DOE: Design of experiments

AA8006: Aluminum AA8006 alloy

ANOVA: Analysis of variance

$\mathrm{S} / \mathrm{N}$ ratio: Signal to noise ratio

SEM: $\quad$ Scanning electron microscopy

WZ: Weld zone

PMZ: $\quad$ Partially melted zone

FSW: $\quad$ Friction stir welding process

EDM: $\quad$ Electrical discharge machining

wt.\%: Weight percentage

DGRA: Desirability grey rotational analysis

MPa: Mega pascal

J: Joules

$\mathrm{mm} / \mathrm{min}$ : Millimeters per minute

Amps: Ampere

HRB: Hardness Rockwell B
UTM: Universal testing machine

PC: $\quad$ Peak current

BC: $\quad$ Base current

WS: Welding speed

3D: $\quad$ Three dimensional

DF: Total degrees of freedom

Seq SS: Sequential sums of squares

Adj SS: Adjusted sums of squares

Adj MS: Adjusted mean squares

F-value: The test statistic utilized

$P$ value: Probability value.

\section{Data Availability}

The data used to support the findings of this study are included within the article.

\section{Conflicts of Interest}

The authors declare that there are no conflicts of interest regarding the publication of this article.

\section{References}

[1] D. Varshney and K. Kumar, "Application and use of different aluminium alloys with respect to workability, strength and welding parameter optimization," Ain Shams Engineering Journal, vol. 12, pp. 1143-1152, 2021.

[2] H. Mehdi and R. S. Mishra, "Effect of friction stir processing on mechanical properties and heat transfer of TIG welded joint of AA6061 and AA7075," Defence Technology, vol. 17, 2020.

[3] Z. Denykui, W. Guoqing, W. Aiping et al., "Study on the inconsistency in mechanical properties of 2219 aluminium alloy TIG-welded joints," Journal of Alloys and Compounds, vol. 777, pp. 1044-1053, 2018.

[4] S. Aravind and A. Daniel Das, "An examination on GTAW samples of 7-series aluminium alloy using response surface methodology," Materials Today, vol. 37, pp. 1-7, 2020.

[5] S. Ramandeep, S. Sukhjindev, and K. Vikas, "Experimental optimization of gas flow rate and current intensity for TIG welding of aluminium alloy," A Journal of Composition Theory, vol. 12, pp. 830-836, 2019.

[6] S. Gurmeet, S. K. Amardee, S. Kulwant, and S. Jagtar, "Experimental comparison of friction stir welding process and TIG welding process for 6082-T6 aluminium alloy," Materials Today, vol. 4, pp. 3590-3600, 2017.

[7] S. Lakshman, S. Rajeshwar, S. Naveen Kumar, S. Davinder, and S. Pargat, "An evaluation of TIG welding parametric influence on tensile strength of 5083 aluminium alloy," International Science Index, Mechanical and Mechatronics Engineering, vol. 7, pp. 2326-2329, 2013.

[8] D. Ji-Kun, W. Dong-Po, W. Ying, and D. Hui, "Effect of post weld heat treatment on properties of variable polarity TIG welded AA2219 aluminium alloy joints," Transactions of Nonferrous Metals Society of China, vol. 24, pp. 1307-1316, 2014.

[9] M. Temmar, M. Hadji, and T. Sahraoui, "Effect of post-weld aging treatment on mechanical properties of tungsten inert gas welded low thickness 7075 aluminium alloy joints," Materials \& Design, vol. 32, no. 6, pp. 3532-3536, 2011. 
[10] R. Adalarasan and M. Santhanakumar, "Parameter design in fusion welding of AA 6061 aluminium alloy using desirability grey relational analysis (DGRA) method," Journal of the Institution of Engineers: Series C, vol. 96, no. 1, pp. 57-63, 2014.

[11] S. Sethuraman, D. Balaji, V. Sivaramakrishnan, and M. Sudhahar, "Optimization of GTAW process parameters on aluminum alloy 6063 on Taguchi method," International Research Journal of Engineering and Technology, vol. 5, pp. 1129-1135, 2018.

[12] S. Shanavas and J. Edwin Raja Dhas, "Weldability of AA5052 H32 aluminium alloy by TIG welding and FSW process - a comparative study," IOP Conference Series: Materials Science and Engineering, vol. 247, pp. 1-8, 2017.

[13] H. Mehdi and R. S. Mishra, "Analysis of material flow and heat transfer in reverse dual rotation friction stir welding: a review," International Journal of Steel Structures, vol. 19, no. 2, pp. 422-434, 2019.

[14] H. Mehdi and R. S. Mishra, "Study of the influence of friction stir processing on tungsten inert gas welding of different aluminum alloy," SN Applied Sciences, vol. 1, pp. 712-2019, 2018.

[15] H. Mohammadzadeh Jamalian, M. Farahani, M. K. Besharati Givi, and V. Majid, "Study on the effects of friction stir welding process parameters on the microstructure and mechanical properties of 5086-H34 aluminum welded joints," International Journal of Advanced Manufacturing Technology, vol. 83, pp. 611-21, 2016.

[16] S. Kasman and Z. Yenier, "Analyzing dissimilar friction stir welding of AA5754/AA7075," International Journal of Advanced Manufacturing Technology, vol. 70, pp. 145-56, 2014.

[17] Y. Li, D. Sun, and W. Gong, "Effect of tool rotational speed on the microstructure and mechanical properties of Bobbin tool friction stir welded 6082-T6 aluminum alloy," Metals, vol. 9, no. 8, Article ID 894, 2019.

[18] F. Taheri-Behrooz, R. M. Aliha Mohammad, M. Maroofi, and V. Hadizadeh, "Residual stresses measurement in the butt joint welded metals using FSW and TIG methods," Steel and Composite Structures, vol. 28, no. 6, pp. 759-766, 2018.

[19] C. Zhang, W. Wang, X. Jin, C. Rong, and Z. Qin, “A study on microstructure and mechanical properties of micro friction stir welded ultrathin al-1060 sheets by the shoulder less tool," Metals, vol. 9, no. 5, Article ID 507, 2019.

[20] K. Devireddy, V. Devuri, M. Cheepu Murali, and B. Kranthi Kumar, "Analysis of the influence of friction stir processing on gas tungsten arc welding of 2024 aluminum alloy weld zone," International Journal of Mechanical and Production Engineering Research and Development, vol. 8, no. 1, pp. 243-52, 2018.

[21] S. Mabuwa and V. Msomi, "Effect of friction stir processing on gas tungsten arc welded and friction stir-welded 5083-H111 aluminium alloy joints," Advances in Materials Science and Engineering, vol. 2019, Article ID 3510236, 14 pages, 2019.

[22] M. Ishak, F. M. Noordin Nur, and H. A. Shah Luqman, "Feasibility study on joining dissimilar aluminum alloys aa6061 and aa7075 by tungsten inert gas (TIG)," Jurnal Teknologi, vol. 75, no. 7, pp. 79-e84, 2015.

[23] Li Hui, Z. Jiasheng, Y. Junshan, and P. Haoping, "The effect of TIG welding techniques on microstructure, properties and porosity of the welded joint of 2219 aluminum alloy," Journal of Alloys and Compounds, vol. 727, pp. 1-8, 2017.

[24] C. P. Pankaj and P. R. D. Shelke, "Review on welding parameter effects on TIG welding of aluminium alloy," International Journal of Engineering Research and General Science, vol. 3, pp. 1479-1486, 2015.
[25] C. Rajendran, K. Srinivasan, V. Balasubramanian, H. Balaji, and P. Selvaraj, "Evaluation of load-carrying capabilities of friction stir welded, TIG welded and riveted joints of AA2014T6 aluminium alloy," Aircraft Engineering \& Aerospace Technology, vol. 91, pp. 1238-1244, 2019.

[26] K. Sanjeev, "Experimental Investigations on pulsed TIG welding of aluminium plate," International Journal of Advances in Engineering \& Technology, vol. I, pp. 1-12, 2010.

[27] P. K. Jayashree, S. S. Sharma, S. Raviraj, M. Ashish, and M. C. Gowrishankar, "Optimization of TIG welding parameters for 6061Al alloy using Taguchi's design of experiments," Materials Today, vol. 5, pp. 23648-23655, 2018.

[28] L. H. Shah, U. K. Mohamad, K. I. Yaakob, A. R. Razali, and M. Ishak, "Lap joint dissimilar welding of aluminium AA6061 and galvanized iron using TIG welding," Journal of Mechanical Engineering and Sciences, vol. 10, pp. 1817-1826, 2016.

[29] J. Pasupathy and V. Ravisankar, "Parametric optimization of TIG welding parameters using Taguchi method for dissimilar joint," International Journal of Scientific Engineering and Research, vol. 4, pp. 25-28, 2013.

[30] A. BalaramNaik and A. ChennakeshavaReddy, "Optimization of tensile strength in TIG welding using the Taguchi method and analysis of variance (ANOVA)," Thermal Science and Engineering Progress, vol. 8, pp. 327-339, 2018.

[31] T. Yashwant, K. Khushmeet, and K. Krishan, "Influences of TIG welding parameters on tensile and impact behaviour of aluminium alloy joints: a review," IOSR Journal of Mechanical and Civil Engineering, vol. 8, pp. 54-58, 2016.

[32] M. Ishak, N. F. M. Noordin, A. S. K. Razali, L. H. A. Shah, and F. R. M. Romlay, "Effect of filler on weld metal structure of AA6061 aluminum alloy by tungsten inert gas welding," International Journal of Automotive and Mechanical Engineering, vol. 11, pp. 2438-2446, 2015.

[33] T. S. Kora, J. Joby, S. M. Georgekutty, and M. Jeeno, “A Review on mechanical \& microstructural property evaluation of aluminium 5083 alloy weldment," International Journal of Mechanical and Production Engineering Research and Development, vol. 3, pp. 119-128, 2013.

[34] M. Subhasmita and A. M. Mohanty, "Performance analysis of TIG welding on Al alloy by using Taguchi method," International Journal of Multidisciplinary Research and Development, vol. 3, pp. 05-08, 2016.

[35] T. Sivasankaran, "Optimization of TIG welding for maximizing weld strength of aluminium 8011," International Journal of Innovative Research in Science, Engineering and Technology, vol. 4, pp. 1735-1743, 2015.

[36] K. M. Eazhil, R. Sudhakaran, M. Jayakumar, R. Govinadaraj, and L. Senthilkumar, "Optimization of the process parameter to maximize the tensile strength in 6063 aluminum alloy using grey based Taguchi method," Advances in Natural and Applied Sciences, vol. 11, pp. 235-241, 2017.

[37] P. Chetan, P. Hemant, and P. Hiralal, "Experimental investigation of hardness of FSW and TIG joints of aluminium alloy of AA7075 and AA6061," Frattura ed Integrità Strutturale, vol. 10, pp. 325-332, 2016.

[38] S. Talu, "Micro and nanoscale characterization of three dimensional surfaces," Basics and Applications, Napoca Star Publishing House, Cluj-Napoca, Romania, 2015. 